
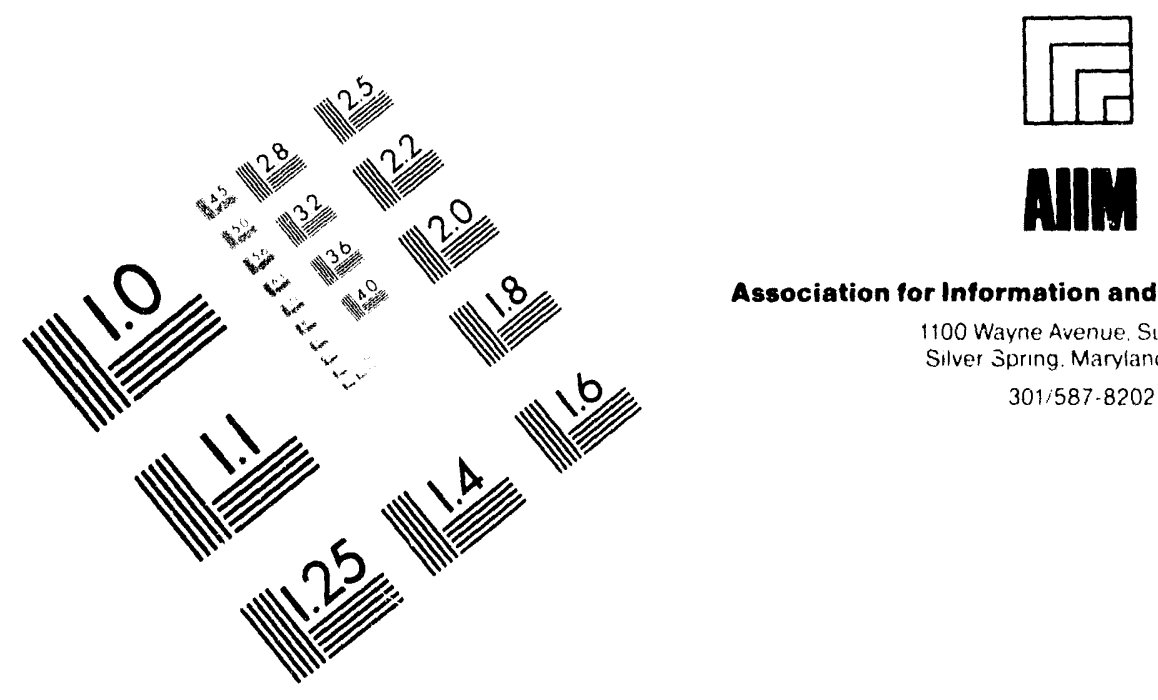

Association for Information and Image Management

1100 Wayne Avenue. Sulte 1100

Silver Spring. Maryland 20910

$301 / 587-8202$

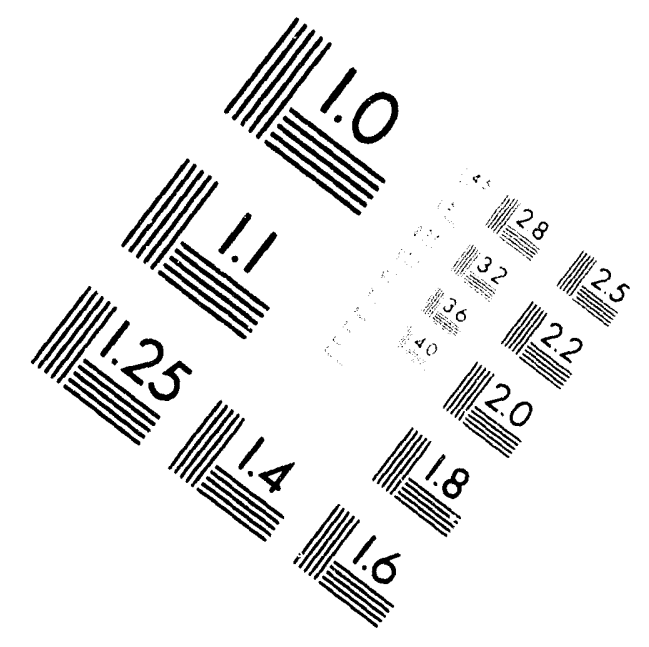

Centimeter

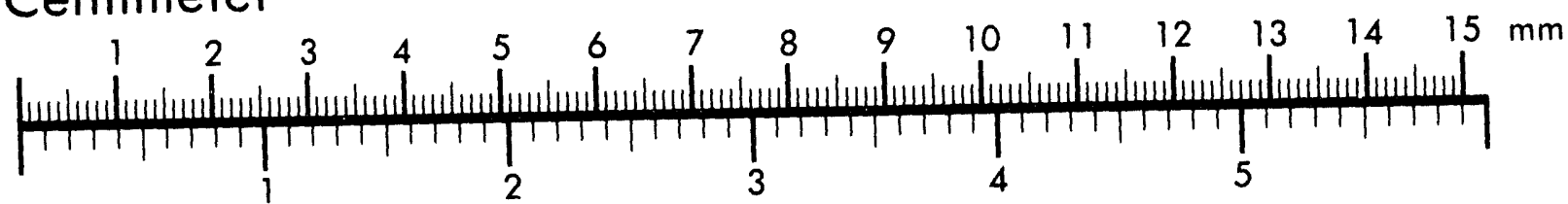

Inches
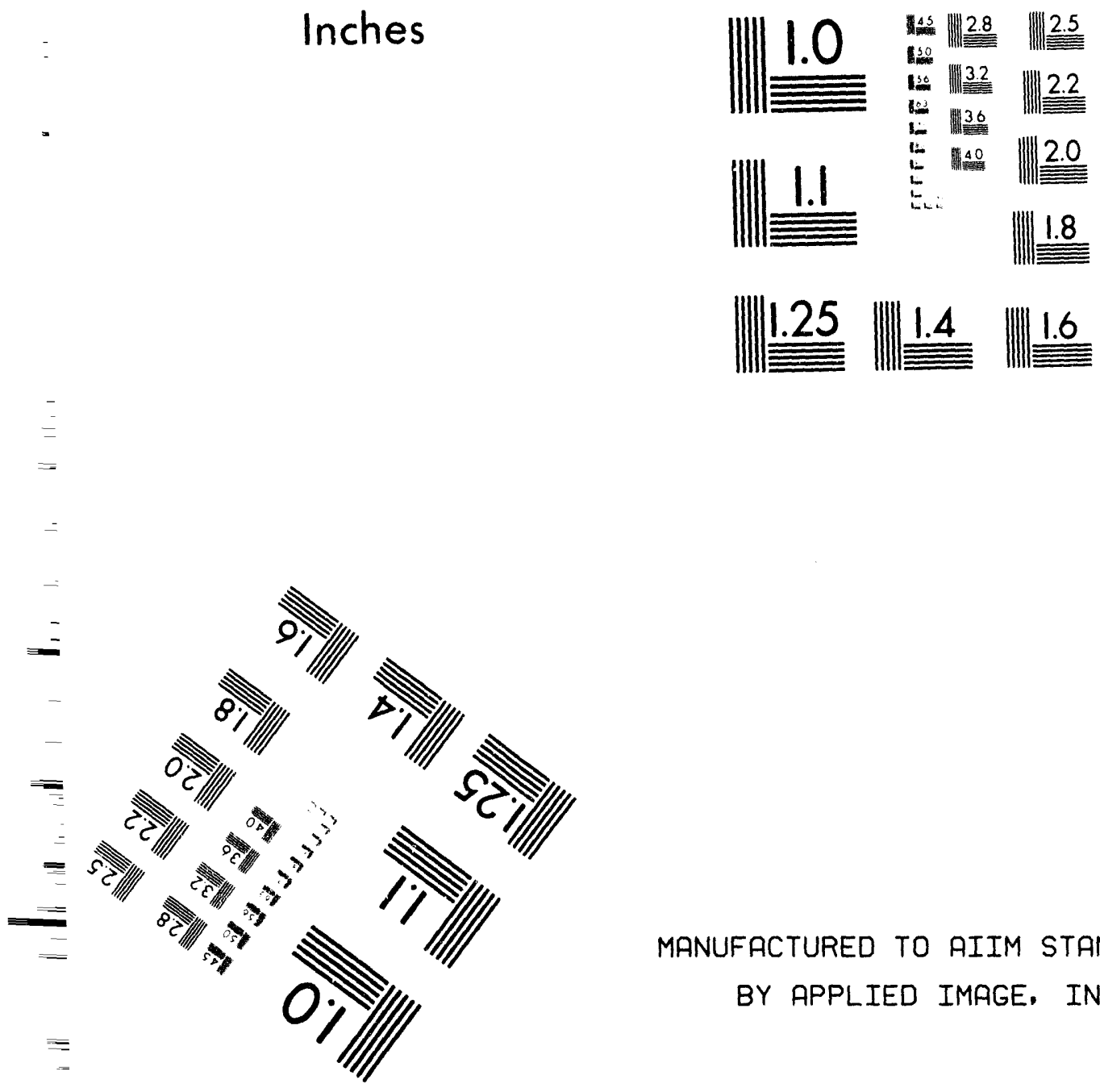

MANUFACTURED TO AIIM STANDARDS

BY APPLIED IMAGE, INC.

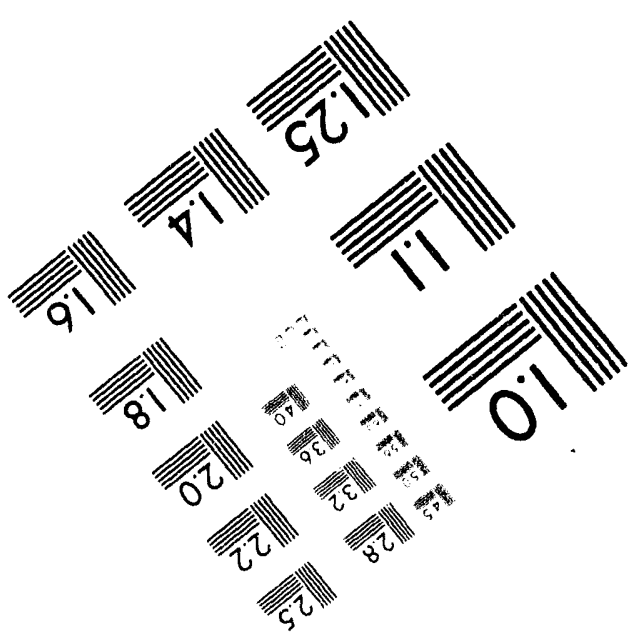



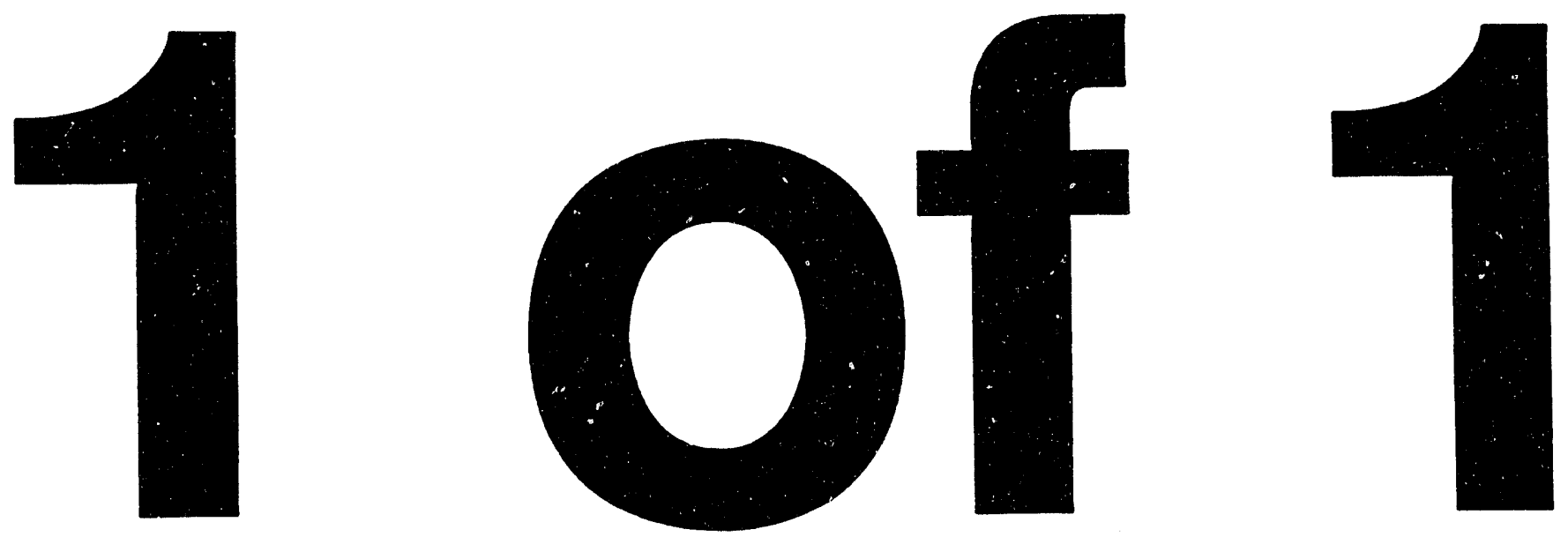
Chemical Technology Division

\section{PRELIMINARY ANALYSIS OF THE ORNL LQUID LOW-LEVEL WASTE SYSTEM}

T. J. Abraham

S. M. DePaoli

S. M. Robinson

A. B. Walker

Date Published: August 1994
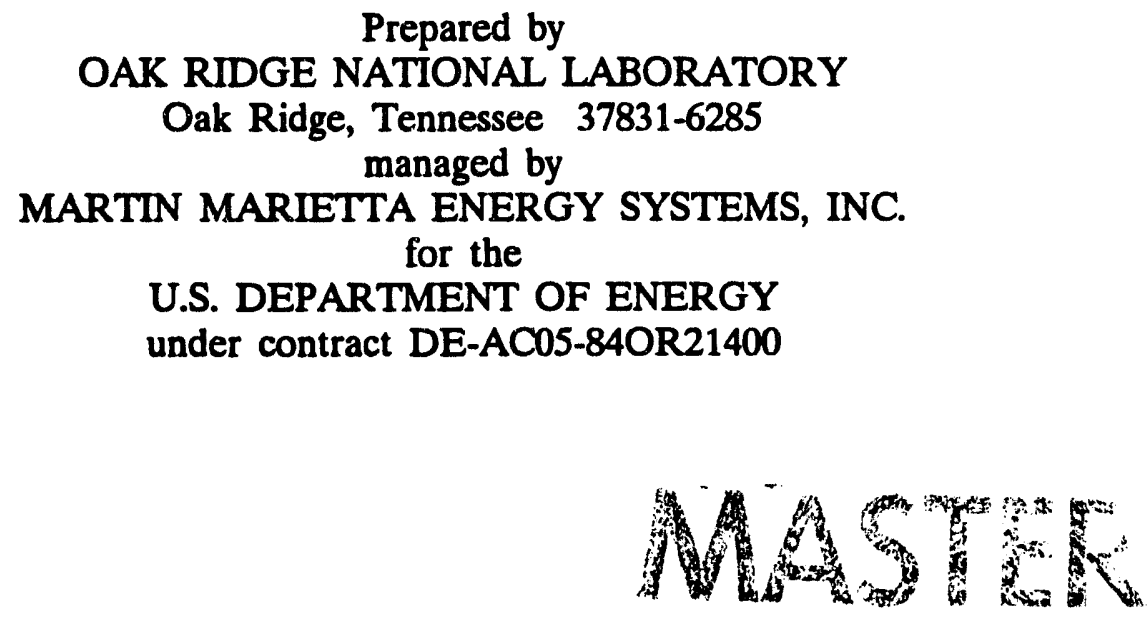

DISTRLBUTION OF THIS DOCUMENT IS UNLIMITED 870 
LIST OF TABLES $\ldots \ldots \ldots \ldots \ldots \ldots \ldots \ldots \ldots \ldots \ldots \ldots$

LIST OF FIGURES $\ldots \ldots \ldots \ldots \ldots \ldots \ldots \ldots \ldots$ vii

PREFACE $\ldots \ldots \ldots \ldots \ldots \ldots \ldots \ldots \ldots \ldots \ldots \ldots \ldots \ldots$

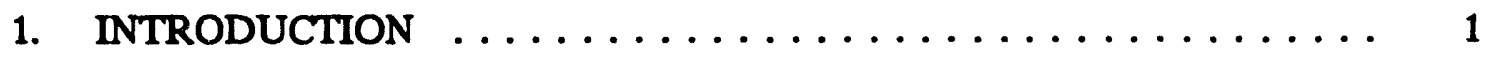

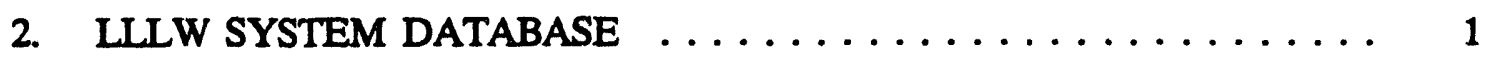

2.1 LLLW GENERATOR (SOURCE) INFORMATION ........ 3

2.2 LLLW COLLECTION TANK DATA .............. 3

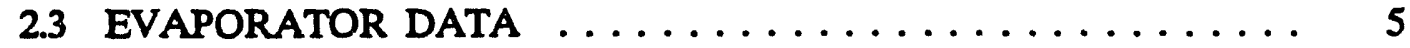

2.4 CONCENTRATE DATA .................... 5

2.5 DEVELOPMENT PLANS FOR THE LLLW SYSTEM DATABASE 6

3. LIQUID LOW-LEVEL WASTE SYSTEM $\ldots \ldots \ldots \ldots \ldots \ldots \ldots \ldots$

3.1 KLLW COLLECTION SYSTEM . . . . . . . . . . . . 8

3.2 LLLW EVAPORATOR FACILITY . . . . . . . . . . . . 12

3.3 LLLW EVAPORATOR FACILITY COMPLEX . . . . . . . . 12

3.4 LLLW CONCENTRATE STORAGE TANKS . . . . . . . . . . 16

4. LLLW SOURCES AND GENERATION $\ldots \ldots \ldots \ldots \ldots \ldots \ldots$

4.1 LLLW GENERATORS . . . . . . . . . . . . . . . 17

4.1 .1 Isotopes Area . . . . . . . . . . . . . . . . . . 23

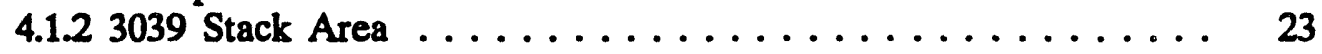

4.1.3 High Flux Isotopes Reactor . . . . . . . . . . . . . . . 25

4.1.4 Oak Ridge Reactor/Bulk Shielding Reactor/Oid Graphite

Reactor ....................... 25

4.1.5 Fission Products Development Laboratory . . . . . . . . . . . 26

4.1.5 High Radiation Level Examination Laboratory . . . . . . . . . . 27

4.1.7 4500 Complex . . . . . . . . . . . . . . . . . . 27

4.1.8 Radiochemical Engineering Development Center . . . . . . . 28

4.1 .9 Overall System Collection Rates . . . . . . . . . . 28

4.2 RAINFALL INLEAKAGE INTO THE LLLW SYSTEM . . . . . . 31

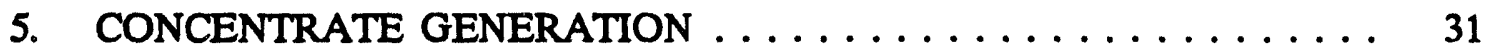

5.1 SOLIDIFICATION OF LLLW CONCENTRATE . . . . . . . . . . 34

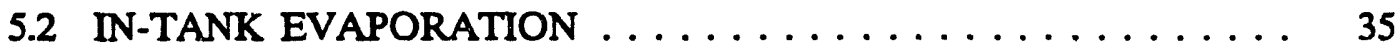

5.3 LLLW CONCENTRATE GENERATION . . . . . . . . . . . . 37

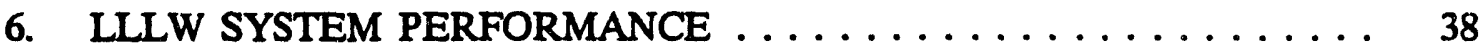

6.1 DATA SOURCES AND COLLECTION $\ldots \ldots \ldots \ldots \ldots \ldots \ldots$ 
6.2 DATA ANALYSIS . . . . . . . . . . . . . . . . . . 39

6.2.1 Relationship Between VRF and LLLW Collections from Specific Generaiois ................... 39

6.2.2 Operational Variability .................. 41

6.3 RESULTS ............................ 43

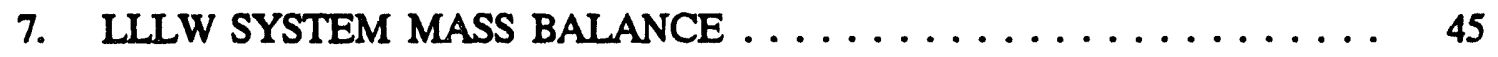

8. CONCLUSIONS AND RECOMMENDATIONS ............ 51

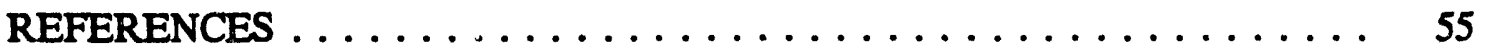




\section{LIST OF TABLES}

Table

1. 1988 LLLW generation rates: Liquid and Gaseous Waste Operations (WOCC) data vs generator estimates ............. 4

2. Collection tanks' capacities and source buildings $\ldots \ldots \ldots \ldots \ldots$

3. Division's contributions to dilute LLLW generation 1986-1989 $\ldots \ldots$. . . . 18

4. Average monthly dilute LLLW generation (for period January 1986-June 1989) $\ldots \ldots \ldots \ldots \ldots \ldots \ldots$

5. Average monthly dilute LLLW generation for $1986 \ldots \ldots \ldots$

6. Average monthly dilute $\operatorname{LLLW}$ generation for $1987 \ldots \ldots \ldots$

7. Average monthly dilute LLLW generation for $1988 \ldots \ldots \ldots \ldots$

8. Average monthly dilute $L L L W$ generation for $1989 \ldots \ldots \ldots$

9. Annual LLLW stream components for the Isotopes Area . . . . . . . . 24

10. Annual LILW stream components for the 4500 complex . . . . . . . 29

11. Annual LLLW stream components for the REDC . . . . . . . . . 30

12. Summary of annual LLLW production rates $\ldots \ldots \ldots \ldots \ldots$

13. Liquid low-level waste concentrate tank volumes and capacities . . . . . 35

14. LLLW concentrate generation, $1986-1990 \ldots \ldots \ldots \ldots \ldots \ldots$

15. LLLW evaporator data, $1986-1988 \ldots \ldots \ldots \ldots \ldots \ldots$

16. LLLW evaporator data, $1987-1988 \ldots \ldots \ldots \ldots \ldots \ldots$

17. Mass flow of nonradiological components in the LLLW system (for stream numbers, refer to Fig. 12) . . . . . . . . . . . . 46,47

18. Curie flow of radiological components in the LLLW system (for stream numbers, refer to Fig. 12) . . . . . . . . . . . . 48,49 


\section{LIST OF FIGURES}

\section{Figure}

1. Liquid low-level waste (LLLW) database menu structure . . . . . . . 2

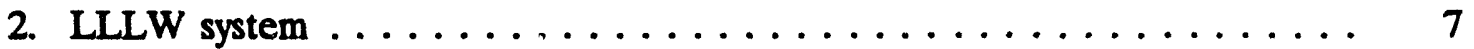

3. Location of the active $\operatorname{LLLW}$ collection tanks . . . . . . . . . 9

4. Typical low-level waste collection tank . . . . . . . . . . . . . 11

5. Underground LLLW transfer line between Bethel Valley and Melton Valley ............................. 13

6. Plan view of the Radioactive Waste Evaporator Facility (Bldg. 2531) . . . 14

7. LLLW generation plotted as a function of rainfall for CY $1988 \ldots \ldots 32$

8. Time-ordered plot of LLLW and rainfall collected during CY $1988 \ldots \ldots 33$

9. LLLW concentrate storage volume occupied over time period 1985-1989 . . . . . . . . . . . . . . . . . . . . . . . 36

10. Volume reduction factor (VRF) as a function of dilute LLLW fed to the

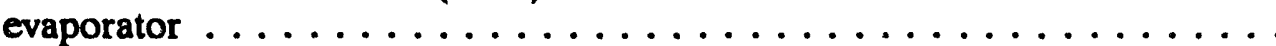

11. Evaporator performance 1986-1988: VRF as a function of average feed

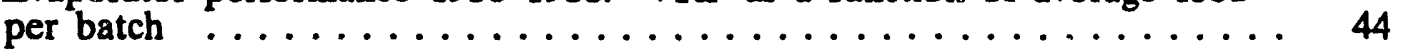

12. Stream designations for generators of $L L L W \ldots \ldots \ldots \ldots$

13. Present status of the LLLW database $\ldots \ldots \ldots \ldots \ldots \ldots$ 


\section{PREFACE}

This report documents liquid low-level waste (LLLW) generation from 1986 through mid-1990. The report was written and submitted in draft form in 1990; however, it was not published in final form. Information contained within the report is accurate for the time it was written; however, several changes have been incurred in the LLLW system since that time. The report has not been updated to reflect these changes but is submitted as is to serve as a companion to report ORNL/TM-12638,

Liquid Low-Level Waste Generation Projections for ORNL in 1993, which summarizes LLLW generation from 1990 through 1993. 


\section{PREILIMINARY ANALYSIS OF THE ORNL LIQUID \\ LOW-LEVEL WASTE SYSTEM}

T. J. Abraham

S. M. DePaoli

A. B. Walker

S. M. Robinson

\section{INTRODUCTION}

The objective of this report is to summarize the status of the Liquid Low-Level Waste (LLLW) Systems Analysis project. The focus of this project has been to collect and tabulate data concerning the LLLW system, analyze the current LLLW system operation, and develop the information necessary for the development of long-term treatment options for the LLLW generated at ORNL.

The data used in this report were collected through a survey of Oak Ridge National Laboratory (ORNL) literature, various letter reports, and a survey of all current LLLW generators. These data are also being compiled in a user friendly database for ORNL-wide distribution. The database will allow the quick retrieval of all information collected on the ORNL LLLW system and will greatly benefit any LLLW analysis effort. This report summarizes the results for the analyses performed to date on the LLLW system.

\section{LLLW SYSTEM DATABASE}

A database has been developed in DBASE III + to store, retrieve, and analyze information concerning the LLLW system at ORNL. Menus are being written to enable people who are unfamiliar with DBASE to use the database. When completed, the database will be accessible through a user friendly software program that will not require the presence of DBASE on the personal computer.

The structure of the database has been previously summarized in a letter report to C. H. Brown, Jr., entitled "Compilation of LLLW Systems Data," dated March 31, 1989. Figure 1 shows the basic structure of the menu-driven software that will enable users to retrieve data. 


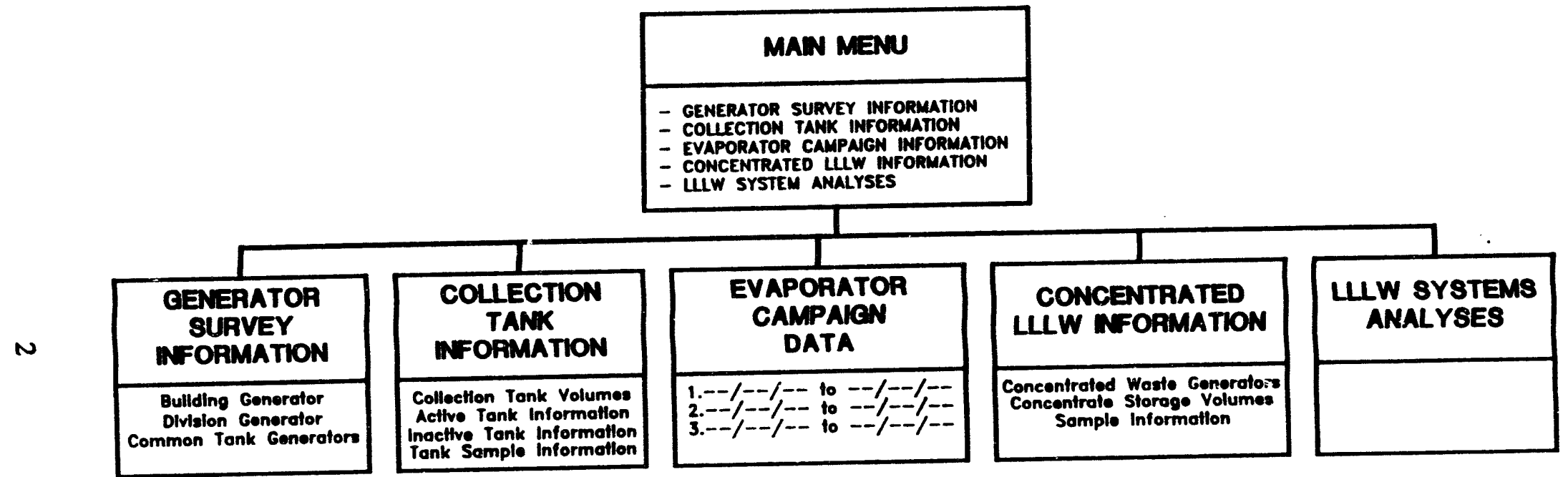

Fig. 1. Liquid low-level waste (LLWW) database menu structure. 
Information contained in the database includes (1) LLLW generator (source) information, (2) LLLW collection tank data, (3) evaporator/evaporation data, and (4) LLLW concentrate data. Some analysis of the data will be included as an option from the main menu. These data, in addition to being accessible as a database, are summarized in the following sections of this report. The data have been extensively analyzed, and this analysis produced the input for this report.

\section{LLLW GENERATOR (SOURCE) INFORMATION}

Generator information has been obtained through the help of the Liquid Generation Certification Officials (LGCOs), who were appointed by their divisions to provide data concerning liquid wastes (low-level and process) generated in their particular area. The information from the LGCOs contained in the database includes estimated LLLW generation volumes, waste contaminants (chemical and radioactive), predictions of future waste generation, and waste pretreatment steps currently in use, if any. General descriptions of the activities performed in the areas are also included.

Table 1 compares the 1988 dilute LLLW generation rates as reported by the Liquid and Gaseous Waste Group in the Environmental and Health Protection (E\&HP) Division vs those estimated rates as provided by LGCOs. In addition, the amount of rainwater collected in tanks that were identified as being significantly influenced by rainfall (Sect. 4.2) are included. As Table 1 demonstrates, the total monthly volume generation rates compare very favorably, particularly when rainfall influence is taken into account. This information, with estimates of radioactive and other contaminates provided by the LGCOs as well as direct sampling data, has been used to construct a mass balance of the LLW system. This mass balance is presented in Chap. 7.

\section{LLLW COLLECTION TANK DATA}

Daily LLLW collection volume data have been obtained from the weekly summary reports distributed by the Liquid and Gaseous Waste Operations Group of the E\&HP Division and are included in the database. These reports were first distributed in 1986, and all reports have been entered into the database. The levels in 
Table 1. 1988 LLLW generation rates: Liquid and Gaseous Waste Operations (WOCC) ${ }^{a}$ data vs generator estimates

\begin{tabular}{|c|c|c|c|c|}
\hline Building/area served & Tank & $\begin{array}{c}1988 \\
\text { monthly } \\
\text { average per } \\
\text { WOCC (gal) }\end{array}$ & $\begin{array}{l}\text { Generator- } \\
\text { estimated } \\
\text { monthly } \\
\text { average (gal) }\end{array}$ & $\begin{array}{c}\text { Rainfall } \\
\text { collection for } \\
\text { specific tanks } \\
\text { (gal/month) }\end{array}$ \\
\hline Isotope areac & WC-10 & 1,611 & 861 & \\
\hline 3039 stack area & W-22 & 3,275 & 3,275 & \\
\hline Reactors & WC-19 & 1,378 & 1,062 & 829 \\
\hline Abandoned & W-1A & 1,161 & 0 & 2,394 \\
\hline Bldg. 2026 & 2026 & 84 & 1 & \\
\hline Bldgs. 4500N, 4505, 4507 & WC-11 & 594 & 0 & 346 \\
\hline Bldes. 4505, 4507 & WC-12 & 180 & 130 & \\
\hline $\begin{array}{l}\text { Bldgs. } 4500 \mathrm{~N}, 4500 \mathrm{~S}, 4501 \text {, } \\
4508\end{array}$ & WC-13 & 667 & 121 & \\
\hline Bldg. 4501 & WC-14 & 163 & 41 & \\
\hline Bldg. 3517 & W.22 & 3,150 & 2,836 & 513 \\
\hline Pump pit & WC-8 & 537 & 537 & \\
\hline Bldg. 3503 \& off-gas drain & WC-9 & 337 & 337 & \\
\hline Bldg. 3508 & WC-5, WC-6 & 160 & 0 & 104 \\
\hline Bldg. 3525 & $\mathrm{~W}-12$ & 1,857 & 900 & \\
\hline Bldg. 3544 feed & W-22 & 652 & 652 & \\
\hline Bldg. 7920 (REDC) & WC-20 & 1,742 & 1,753 & \\
\hline Bldg. 7900 (HFIR) & HFIR & 2,996 & 3,029 & \\
\hline Bldg. 3028 & WC-2 & 91 & 0 & \\
\hline Bldg. 3504 & WC.7 & 21 & 8 & \\
\hline Bldg. 3026D & W-16 & 410 & 0 & \\
\hline Bldg. $3026 \mathrm{C}$ & $W-17 \& W-18$ & 1,745 & 202 & 967 \\
\hline Bldg. 3019 & W-22 & 899 & 890 & \\
\hline Bldg. 3025 & WC-3 & 19 & 18 & \\
\hline Bldg. 3074 & Trucked & 352 & 382 & \\
\hline Bddg. 7602 (EGCR) ad & Trucked & 315 & 500 & \\
\hline Bldg. $7500^{\circ}$ & Trucked & 52 & 52 & \\
\hline Bldg. 2531 sumps, etc. & W-22 & 1,971 & 1,971 & \\
\hline TOTAL & & 26,419 & 19,558 & 5,153 \\
\hline
\end{tabular}

${ }^{a}$ WOCC $=$ Waste Operations Control Center; REDC $=$ Radiochemical Engineering Development Center; HFIR = High Flux Isotope Reactor; EGCR $=$ Experimental Gas-Cooled Reactor.

These volumes exclude those already taken into consideration by the generator and/or Waste Operations. Calculations are based on time series analysis results.

'Isotopes area includes Bldgs. 3028E, 3029, 3030, 3031, 3032, 3033, 3033A, 3038E, and 3047.

${ }^{d}$ EGCR will not be transporting any waste to the LLLW evaporator in 1989.

The LLLW volume from the 7500 area in 1988 was a one-time transfer of $620 \mathrm{gal}$. 
the 22 active LLLW collection tanks are measured daily, and the daily collection volumes are calculated from differences in level changes. Other information in the database concerning the collection tanks includes tank capacities, locations, rainwater inleakage rates, and source buildings that feed each tank. Sample analyses that have been performed on any of the collection tank wastes are kept in the database as well.

\section{EVAPORATOR DATA}

General information concerning the evaporator and evaporator service tanks has been recorded in the database. During operation of the evaporator system, liquid volumes transferred into and out of the evaporators are recorded by the operators. Several thousand gallons of dilute LLLW may be transferred into the evaporator at distinct time intervals before concentrate is removed. This information was analyzed and put into the computer and is referred to as "evaporator campaign" data. A campaign begins with the first transfer of LLLW into the evaporator and ends with the first removal of concentrate. Data beginning in 1986 have been summarized in this way and recorded in the database. These data were analyzed to determine the major contributors of LLLW concentrate. These data also allow volume reduction factors to be calculated.

\section{CONCENTRATE DATA}

Concentrate removed from the evaporator is pumped to one of several storage tanks [Melton Valley Storage Tanks (MVSTs), W-21, W-23, C-1, or C-2]. Routinely generated Process Waste Treatment Plant (PWTP) concentrate is stored in tank W-21. The volumes of concentrate generated are kept in the database, as well as the monthly readings of the liquid levels in the storage tanks. (There is a slight discrepancy between the recorded concentrate volumes generated and the storage tank volume increases because of the accuracy of the instrumentation; therefore, both sets of data are recorded.) Several sample campaigns have been performed on the MVST contents. The analytical results from these sampling campaigns are recorded in the database also. 


\section{DEVELOPMENT PLANS FOR THE LLLW SYSTEM DATABASE}

As mentioned in the Introduction, the database will be accessed by a user friendly, menu-driven software program. A general outline of the menus used to retrieve the data was shown in Fig. 1. The completed work to date includes the programming for the first three selections from the main menu, that is, retrieval of the generator information, the collection tank information, and the evaporator campaign information. Work is continuing on the concentrated LLLW information and system analysis retrieval sys:ems. User documentation will be prepared, and training classes will be held to introduce users to the capabilities of the database as part of the FY 1990 milestone.

\section{LUUID LOW-LEVEL WASTE SYSTEM}

Radioactively contaminated liquid wastes at ORNL are generated by various activities, including research activities that are performed within many divisions, various decontamination activities also practiced throughout several divisions, and reactor operations performed mainly in the Research Reactors Division. Other significant sources of LLLW include the Laboratory's waste treatment facilities, which are the PWTP (Building 3544) and the Central Off-Gas (COG) scrubbing system (Building 3039). A large amount of waste is expected to be generated during remedial actions' cleanup of inactive tanks and facilities during the next 10 years. Further discussion of the LLLW and its sources is found in Chap. 4.

Figure 2 shows a schematic of the LLLW system. LLLW generated by the various activities at the Laboratory is discharged by way of "hot" drains located in laboratory sinks, hoods, floors, and hot cells. In some cases the liquid is collected and trucked. Waste that is discarded down "hot" drains flows by gravity through singly- or doubly-contained pipes to underground stainless steel collection tanks, where the waste is neutralized, if necessary. These primary tanks (and associated piping) are known as the Collection and Transfer (CAT) System. The waste accumulated in the collection tanks is transferred via steam jets or pumps through underground piping to the LLLW Evaporator Facility (Building 2531), where it is concentrated in one of two evaporator units. From there, the concentrated waste is transferred to one of many storage tanks 


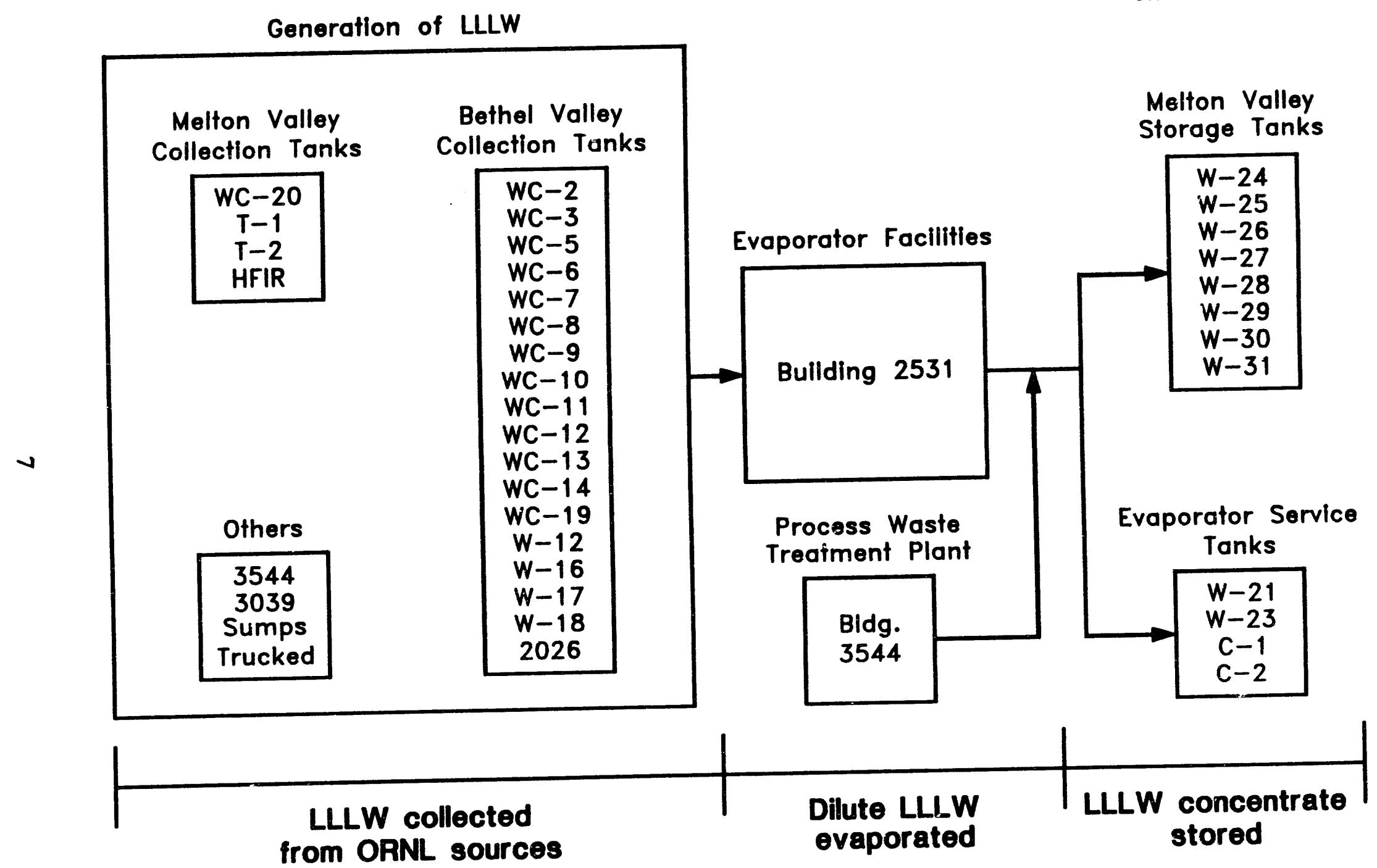

Fig. 2 LLLW system. 
(the MVSTs or Evaporator Service Tanks), and the condensate is transferred to the PWTP for further treatment.

\subsection{LLW COLLECTION SYSTEM}

The CAT System is divided into two branches, the Mel'n Valley branch and the Bethel Valley branch. Currently, there are 22 active collection tanks, 4 tanks that serve the Melton Valley area and 18 tanks that serve the Bethel Valley area. There are 33 inactive collection and storage tanks. The locations of the active collection tanks are shown in Fig. 3. Also shown in the figure is the inactive tank W-1A, which is periodically pumped to the evaporator system because of rainwater inleakage. The collection tanks and their capacities are given in Table 2.

The CAT System was designed in the 1950s. Most of the floor drains, collection tanks, and transfer lines in the system are singly contained. The system was designed to work $\sim 20$ years; however, most of the system is older than this. Current regulations and orders pertaining to this system require doubly-contained piping and tanks, leak detection, and extensive documentation of waste generation. To comply with the regulations, the system is being upgraded and/or replaced. The work is under way and is expected to take -6 years to complete.

Each collection tank is equipped with a sampling device, liquid-level instrumentation, and a filtered vent to the atmosphere or to the off-gas system of the facility that it serves. Underground collection tanks in the Bethel Valley area have $d r y$ wells, which are concrete pads with sumps located at the low point under the tanks and wells extending to the surface of the ground. The dry well serves as a samprling point for groundwater surrounding the tank, an indication of leakage from the tank. A typical tank design is shown in Fig. 4. A network of 0.05- and 0.08-m (2- and 3-in.) stainless steel underground pipelines connects the collection tanks to one of two $0.15-\mathrm{m}$ (6-in.) doubly-contained, stainless steel collection headers that directs the flow through doubly-contained piping to the evaporator feed tank, W-22. Several source buildings send waste from "facility" tanks directly to the collection header at valve box \#2. (These tanks are not owned by E\&HP Division and are not discussed in this document.) Waste is transferred by centrifugal pumps or steam jets. 


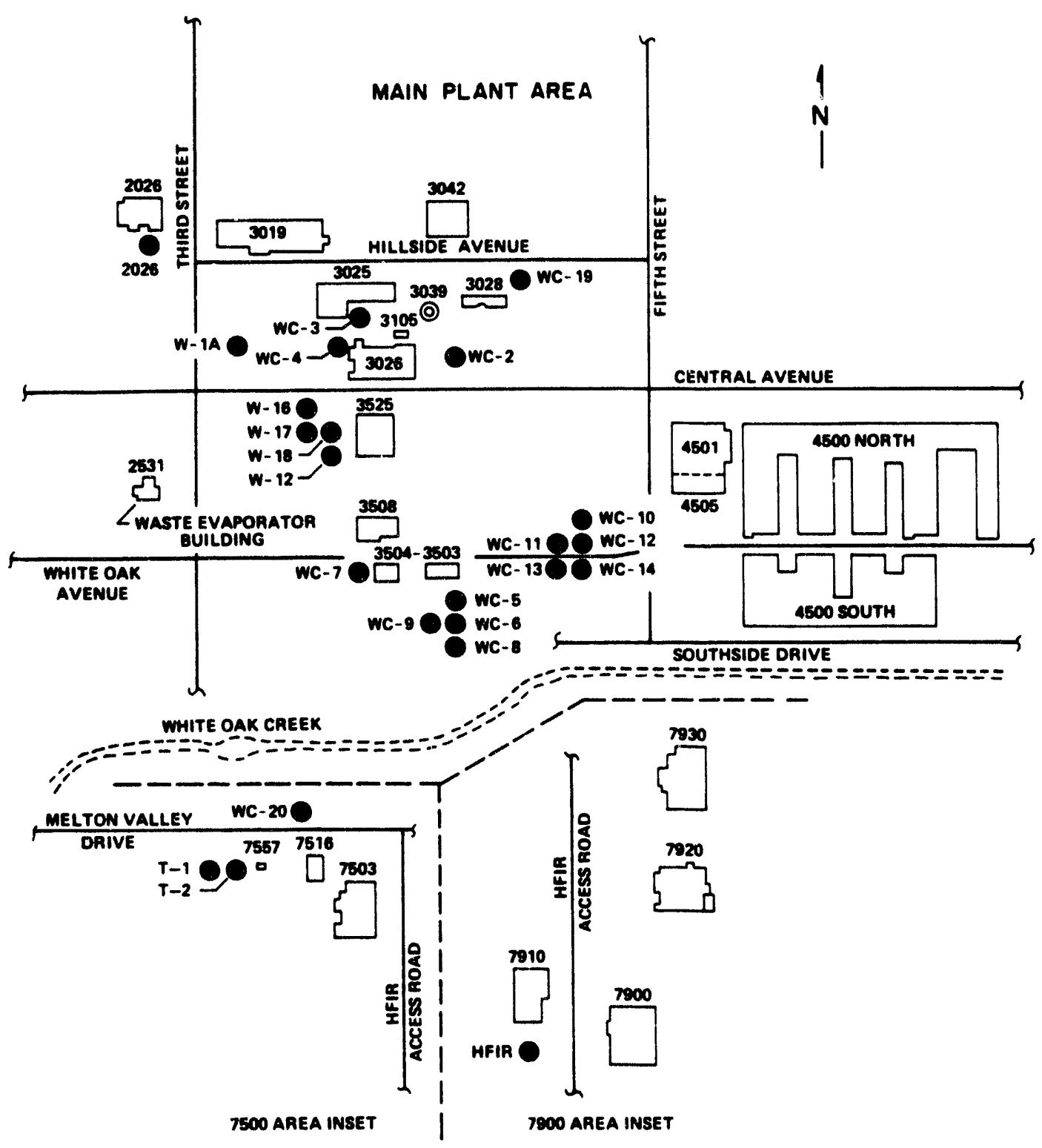

Fig. 3. Location of the active LLLW collection tanks. 
Table 2. Collection tanks' capacities and source buildings

\begin{tabular}{|c|c|c|c|}
\hline Tank & Tank size (gal) & $\begin{array}{c}\text { Tank } \\
\text { location }\end{array}$ & Source building(s) \\
\hline \multicolumn{4}{|c|}{ Bethel Valley Collection Tanks } \\
\hline 2026 & 500 & E. of Bldg. 2026 & 2026 \\
\hline $\mathbf{W}-1 \mathrm{~A}$ & 4,000 & North Tank Farm & (None, tank is inactive) \\
\hline WC.2 & 1,000 & W. of Bldg. 3030 & 3028,3038 \\
\hline WC-3 & 1,000 & S. of Bldg. 3025 & 3025,3098 \\
\hline WC-4 & 1,700 & W. of Bldg. 3026C & (None, tank is inactive) \\
\hline WC.5 & 1,000 & S. of Bldg. 3503 & 3508 \\
\hline WC-6 & 500 & S. of Bldg. 3503 & 3508 \\
\hline WC.7 & 1,100 & W. of Bldg. 3504 & 3504 \\
\hline WC-8 & 1,000 & S. of Bldg. 3503 & Pump pit \\
\hline WC-9 & 2,140 & S. of Bldg. 3503 & 3503, HOG pot \\
\hline WC-10 & 2,300 & S. of Bldg. 3587 & $3028,3029,3030,3031$ \\
\hline & & & $3032,3033,3047,3092$, \\
\hline WC-11 & 4,600 & S. of Bldg. 3587 & $4500 \mathrm{~N}, 4505,4507$ \\
\hline WC-12 & 1,000 & S. of Bldg. 3587 & 4505 \\
\hline WC-13 & 1,000 & S. of Bldg. 3587 & $4500 \mathrm{~N}, 4500 \mathrm{~S}, 4501,4508$ \\
\hline WC-14 & 1,000 & S. of Bldg. 3587 & 4501 \\
\hline WC-19 & 2,100 & S. of Bldg. 3587 & $3001,3002,3003,3004$ \\
\hline & & & $3005,3008,3042,3109$ \\
\hline & & & 3119 \\
\hline W-12 & 700 & South Tank Farm & 3525 \\
\hline W-16 & 1,000 & South Tank Farm & 3026D \\
\hline W-17 & 1,000 & South Tank Farm & $3026 \mathrm{C}$ \\
\hline W-18 & 1,000 & South Tank Farm & $3026 \mathrm{C}$ \\
\hline \multicolumn{4}{|c|}{ Melton Valley Collection Tanks } \\
\hline WC-20 & 10,000 & Melton Valley & 7920,7930 \\
\hline T-1 & 15,000 & Melton Valley & $7500,7503,7900,7911$, \\
\hline & & Melton Valley & $7913,7920,{ }^{a} 7930^{\circ}$ \\
\hline \multirow[t]{2}{*}{$T-2$} & 15,000 & \multirow{3}{*}{ Melton Valley } & $7500,7503,7900,7911$, \\
\hline & & & $7913,7920,{ }^{a} 7930^{\circ}$ \\
\hline HFIR & 13,000 & & $7900,7911,7913$ \\
\hline
\end{tabular}

These facilities do not normally transfer waste to this tank. 


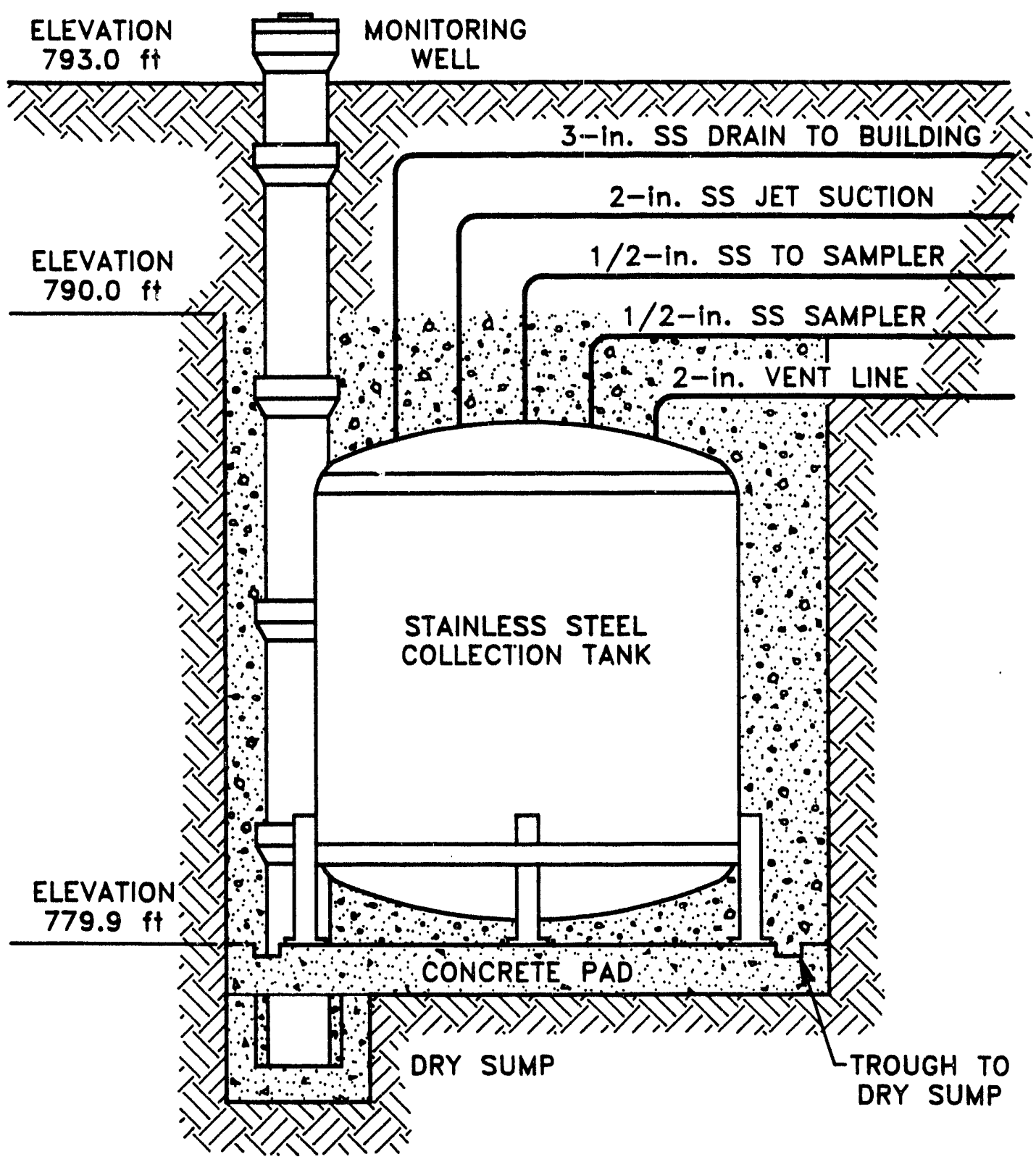

Fig. 4. Typical low-level waste collection tank 


\subsection{LLLW EVAPORATOR FACILTTY}

LLLW solutions that accumulate in the collection tanks are periodically transferred to the evaporator service tank W-22 and then fed to evaporators A2 and $2 \mathrm{A2}$, where the evaporation of the radioactive waste solution is accomplished. The two evaporators are operated in a semicontinuous manner. Dilute LLLW is transferred by steam jet from feed tank W-22 to the evaporator as necessary to maintain a minimum level. The waste is concentrated to a target specific gravity of approximately 1.25. The evaporator condensate, which contains trace amounts of radionuclides, is directed to the PWTP.

When the evaporator bottoms or concentrated waste reaches a specific gravity of about 1.25 , or when there is no feed left to process, the evaporator is shut down, the contents cooled, and then the "concentrate" is jetted to one of the 11 storage tanks that are discussed in more detail in Chap. 5.

The transfer of the concentrate from the evaporator facility to the storage tanks is done through a doubly-contained stainless steel line that is cathodically protected and buried in a bed of specially prepared clay. The transfer route to the Melton Valley area (where the storage tanks are located) is shown in Fig. 5.

\subsection{LLLW EVAPORATOR FACIIITY COMPLEX}

The Radioactive Waste Evaporator Facility (Bldg. 2531) shown in the plan view of Fig. 6 includes the following major areas:

1. Stainless-steel-lined vaults containing the evaporator feed tank W-22, the converted evaporator feed tank W-21 (now a storage tank for concentrated liquid waste, primarily that waste generated by the PWTP), the concentrate storage tank W-23, and associated pumps, pipes, and controls.

2. Underground pipe trench, for the transfer of liquid waste from the feed tank to the evaporator. 


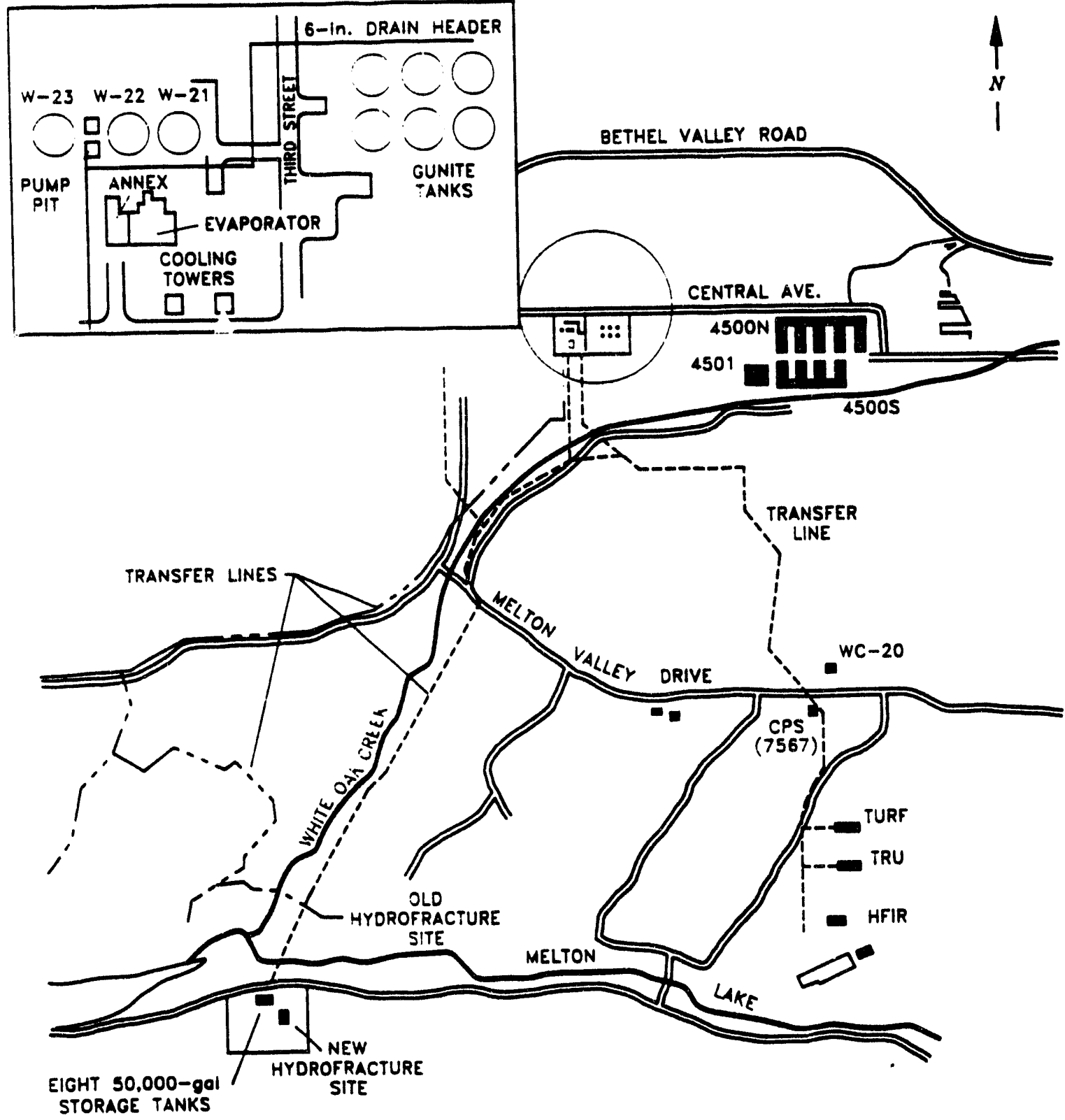

Fig. 5. Underground LLLW transfer line between Bethel Valley and Melton Valley. 


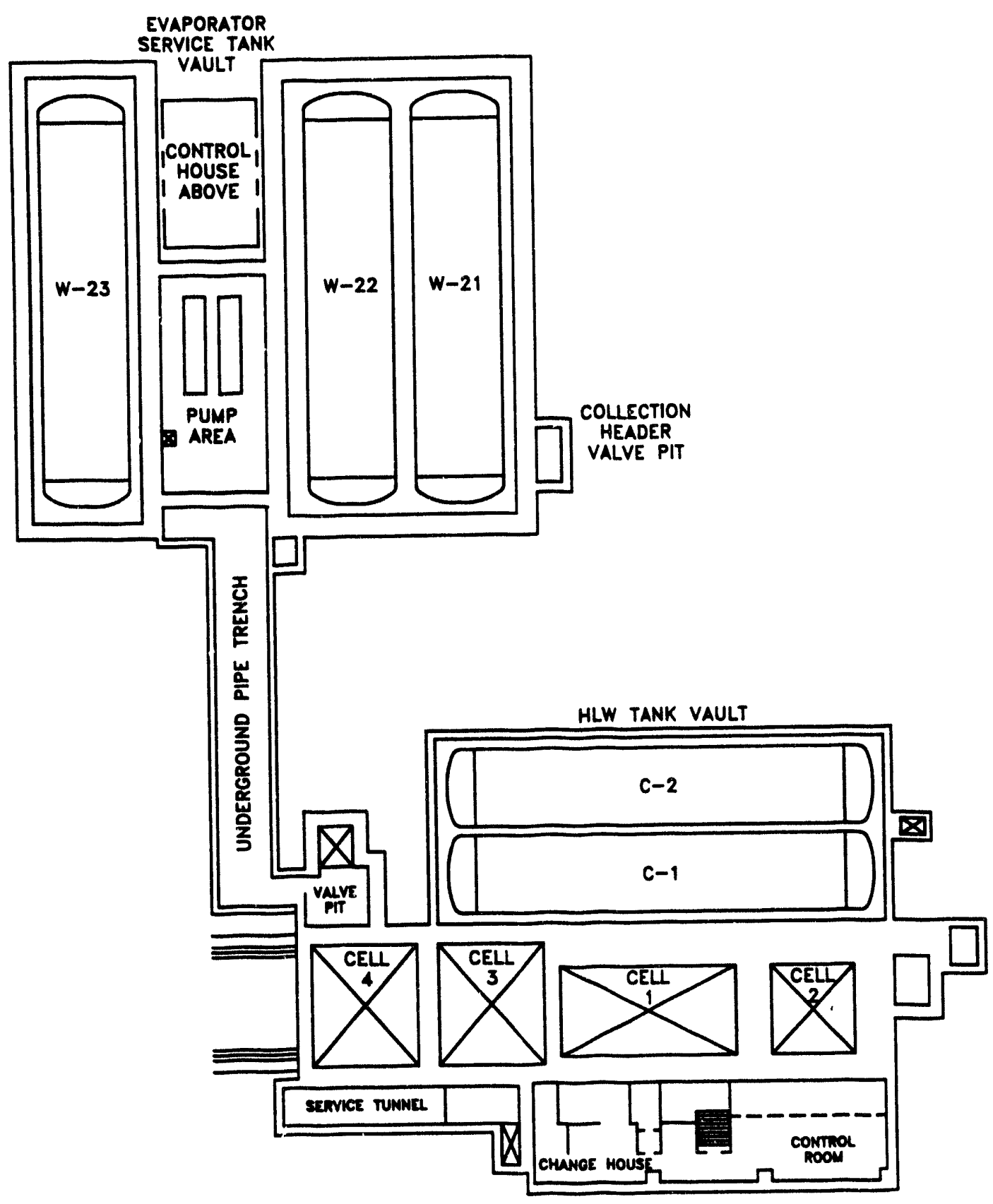

Fig. 6. Plan view of the Radioactive Waste Evaporator Facility (Bldg. 2531). 
3. The high-level waste (HLW) tank vault containing tanks $\mathrm{C}-1$ and $\mathrm{C}-2$, which are now storage tanks for concentrated waste from the evaporator.

4. Cells 1 through 4 in Building 2531 contain the evaporators and associated equipment. Cell 1 contains the original evaporator A-2 and its feed tank, A-1. Cell 2 contains the evaporator's (A-2's) accompanying process equipment: condenser, vapor filter, condensate catch tank, off-gas scrubber, emergency condenser, and scrub liquor tank. Cell 4 holds evaporator 2A-2, and Cell 3 contains the condensate filter, evaporator condenser, condensate surge tank, offgas scrubber, and the scrub liquor tank for evaporator 2A-2. Also in the building are the control room and service tunnel.

The first evaporator, A-2, was installed and started operation in 1965, while the second evaporator, 2A-2, which was built identically to A-2, was installed in the evaporator annex in 1978. The evaporators have a boil-up rate of $\sim 50 \mathrm{lb} / \mathrm{h}$ per square foot of boiling surface. Both e raporators are designed to operate at a rate of $600 \mathrm{gal} / \mathrm{h}$ and are capable of automatic operation except for startup and shutdown. This allows for the evaporators to operate without supervisory personnel present in Building 2531. Automatic alarms triggered by abnormal operating conditions will alert operating personnel in the WOCC, Building 3130, and will cause a shutdown of the evaporator until the alarm condition is corrected by operating personnel.

The evaporator coils, designed for heating or cooling and located in the bottom of the evaporator, are operated at a steam pressure of 35 psig. In both evaporators, a coil is located above the normal liquid level and acts as a foam breaker. Spray nozzles are located near the top of the evaporation tanks for spraying antifoaming agents, and three other spray nozzles provide decontamination solutions to the evaporators.

An impingement-type deentrainer is installed in the top head of the evaporator to ensure that the condensate from the evaporator has a very low level of radioactivity. The deentrained material is carried by a drain back below the surface of the boiling waste. Thus a decontamination factor of between 10,000 and 100,000 is accomplished between the evaporator feed and the vapor leaving the evaporator.

Interlocks and control circuits for both evaporators provide automatic control and dictate that the ventilation system must be operating properly, cooling water must be flowing to the condenser, all radiation monitors must be operating at or below their 
alarm levels, and the condensate sample pump must be operating for continued operation of the evaporator unit.

A spare evaporator vessel was constructed in 1965 and is also identical to unit A-2. This evaporator is presently in storage and is tested periodically to ensure its integrity. The spare evaporator is kept ready in case A-2 or 2A-2 should ever need replacing.

\subsection{LLWW CONCENTRATE STORAGE TANKS}

ORNL has 1250,000 -gal-capacity tanks for the storage of LLLW concentrate. Eight of these tanks, known as the MVSTs, are located on the new Hydrofracture site in an underground, concrete, stainless-steel-lined vault. The other four storage tanks, located near the evaporator facility, are C-1, C-2, W-23, and W-21. Both C-1 and C-2 were originally built to hold HLW, but because HLW is not generated at ORNL, they were repiped to receive $L L L W$ concentrate. Tank W-21, originally a feed tank for the LLLW evaporator, was converted to a tank for storage of concentrate produced by the PWTP in an effort to decouple the PWTP and LLLW operations. Currently, tank W22 serves as the sole evaporator feed tank. Tank W-23 receives concentrate directly from the evaporator. It is normally used as a collection point for LLLW concentrate before it is transferred to the MVSTs for storage.

\section{LULW SOURCES AND GENERATION}

As mentioned briefly in Chap. 3, several facilities contribute to the generation of LLLW. The radioactive liquid waste generated at the Laboratory can be broken down into several types of waste: (1) those wastes that result from air and water treatment facility operations, (2) those wastes that result from decontamination of hot cells and various areas, and (3) waste generated by research and development (R\&D) activities. Of these types of LLLW, air and water treatment facility operations have accounted for $\sim 34 \%$ of the LLLW wastes generated since 1986. Decontamination activities have generated about $45 \%$ of the waste, and other activities, including R\&D activities and rainwater infiltration, account for the other $21 \%$. Contributions of rainfall to the LLLW system are discussed further in Sect. 4.2. 
Table 3 gives a list of those divisions which produce LLLW and corresponding approximate percentages of LLLW generated between 1986 and 1989. As seen in the table, the Chemical Technology Division is the largest producer of LLLW, accounting for almost half of the LLLW generated. Most of these wastes are generated by decontamination activities involving isotope production. The second largest division generator, at $27 \%$, is the E\&HP Division. These wastes consist mainly of air and water treatment residual liquids, those from the PWTP and the COG stack, as well as several small off-gas facilities. Research Reactors Division produced about $23 \%$ of the LLLW generated during these years.

\subsection{LLLW GENERATORS}

As mentioned in Chap. 2, the ORNL LILW system is used to collect, neutralize, concentrate, and store radioactive waste solutions. Annual summaries of the monthly LLLW collected from specific generators are contained in Tables 4-8. Table 4 summarizes collections of LLLW over the period of January 1986 to June 1989, and Tables 5, 6, 7, and 8 summarize monthly LLLW generation rates from 1986, 1987, 1988, and 1989 respectively. As the data in these tables demonstrate, relatively few generators are responsible for the generation of most of the LLLW collected at ORNL since 1986. The primary generators are the Isotopes Area (16\%), the 3039 stack area (11\%), the HFIR (11\%), the ORR and the BSR (10\%), the Fission Products Development Laboratory (FPDL) (10\%), the High Radiation Level Experimentation Laboratory (9\%), the 4500 complex (8\%), the Radiochemical Engineering Development Center (REDC) (4\%), Building 3019 (3\%), and the PWTP spent acid stream (3\%). Descriptions of the activities of specific large LLLW generators follow in the next few sections. Two important LLLW generators will not be described in any detail in this chapter; they are Building 3019, which is expected to be only a minor LLLW generator in the future, and tank W-1A, which is an inactive tank and collects only rainwater. 
Table 3. Division's contributions to dilute LLLW generation, 1986-1989

Average percentage

Division of dilute LLLW generation for 1986-1989

Analytical Chemistry

Chemistry

$<1$

Chemical Technology

Environmental \& Health Protection

27

Environmental Sciences

$<1$

Health and Safety Research

$<1$

Metals and Ceramics

Plant and Equipment

$<1$

$<1$

Research Reactors

23

Table 4. Average monthly dilute LLLW generation (for period January 1986-June 1989)

\begin{tabular}{lcc}
\hline \multicolumn{1}{c}{ Generator } & $\begin{array}{c}\text { Monthly generation } \\
\text { (gal) }\end{array}$ & Percent of total \\
\hline Isotopes $^{a}$ & 5,061 & 16 \\
High Flux Isotope Reactor $^{\text {3039 stack area }}$ & 3,890 & 13 \\
Reactors & 3,552 & 11 \\
Bldg. 3517 & 3,210 & 10 \\
Bldg. 3525 & 3,120 & 10 \\
4500 complex & 2,615 & 8 \\
Tank W-1A & 2,609 & 8 \\
Bldg. 7920 & 2,319 & 8 \\
Bldg. 3019 & 1,370 & 4 \\
PWTP spent acid & 1,061 & 4 \\
Tank WC-8 pump pit & 999 & 3 \\
All others & 545 & 2 \\
& 835 & 3 \\
Total & & \\
\hline
\end{tabular}

-Isotopes include all collections from Isotopes Area collection tanks WC-10 and WC-2, Bldg. 3026C collection tanks W-17 and W-18, and Bldg. 3026D collection tank W-16.

${ }^{b}$ Reactors include the Oak Ridge Research Reactor (ORR), the Old Graphite Reactor (OGR), and the Bulk Shielding Reactor (BSR). 
Table 5. Average monthly dilute LLLW generation for 1986

\begin{tabular}{lcc}
\hline \multicolumn{1}{c}{ Generator } & $\begin{array}{c}\text { Monthly generation } \\
\text { (gal) }\end{array}$ & Percent of total \\
\hline Isotopes $^{a}$ & 7,466 & 17 \\
Reactors $^{b}$ & 5,455 & 13 \\
High Flux Isotope Reactor & 5,370 & 12 \\
4500 complex & 5,110 & 12 \\
Bldg. 3517 & 4,629 & 11 \\
Bldg. 3525 & 3,770 & 9 \\
3039 stack area & 3,480 & 8 \\
PWTP spent acid & 2,130 & 5 \\
Tank W-1A & 1,720 & 4 \\
Bldg. 7920 & 1,608 & 4 \\
Bldg. 3019 & 1,151 & 3 \\
Tank WC-8 pump pit & 534 & 1 \\
All others & 703 & 2 \\
Total & 43,126 & \\
\hline
\end{tabular}

Isotopes include all collections from Isotopes Area collection tanks WC-10 and WC-2, Bldg. 3026C collection tanks W-17 and W-18, and Bldg. 3026D collection tank W-16.

${ }^{b}$ Reactors include the ORR, the OGR, and the BSR. 
Table 6. Average monthly dilute LLLW generation for 1987

\begin{tabular}{|c|c|c|}
\hline Generator & $\begin{array}{c}\text { Monthly generation } \\
\text { (gal) }\end{array}$ & Percent of total \\
\hline Isotopes ${ }^{a}$ & 3,779 & 14 \\
\hline Reactors ${ }^{b}$ & 3,601 & 13 \\
\hline 3039 stack area & 3,539 & 13 \\
\hline Bldg. 3517 & 3,362 & 12 \\
\hline High Flux Isotope Reactor & 2,620 & 10 \\
\hline 4500 complex & 2,419 & 9 \\
\hline Bldg. 3019 & 2,172 & 8 \\
\hline Bldg. 3525 & 1,830 & 7 \\
\hline Bldg. 79.20 & 1,188 & 4 \\
\hline Tank W-1A & 1,004 & 4 \\
\hline PWTP spent acid & 592 & 2 \\
\hline Bldg. 3503 and off-gas drain & 457 & 2 \\
\hline All others & 825 & 2 \\
\hline Total & 25,216 & \\
\hline
\end{tabular}

Isotopes include all collections from Isotopes Area collection tanks WC-10 and WC-2, Bldg. 3026C collection tanks W-17 and W-18, and Bldg. 3026D collection tank W-16.

${ }^{b}$ Reactors include the ORR, the OGR, and the BSR. 
Table 7. Average monthly dilute LLLW generation for 1988

\begin{tabular}{lcc}
\multicolumn{1}{c}{ Generator } & $\begin{array}{c}\text { Monthly generation } \\
\text { (gal) }\end{array}$ & Percent of total \\
\hline Isotopes $^{a}$ & 3,766 & 16 \\
3039 Stack area & 3,275 & 14 \\
Bldg. 3517 & 3,150 & 13 \\
High Flux Isotope Reactor & 2,996 & 12 \\
Bldg. 3525 & 1,857 & 8 \\
Bldg. 7920 & 1,742 & 7 \\
4500 complex & 1,605 & 7 \\
Reactors & \\
Tank W-1A & 1,378 & 6 \\
Bldg. 3019 & 1,161 & 5 \\
PWTP spent acid & 899 & 4 \\
Tank WC-8 pump pit & 652 & 3 \\
All others & 1,064 & 2 \\
Total & 24,082 & 3 \\
\hline
\end{tabular}

Isotopes include all collections from Isotopes Area collection tanks WC-10 and WC-2, Bldg. 3026C collection tanks W-17 and W-18, and Bldg. 3026D collection tank W-16.

${ }^{b}$ Reactors include the ORR, the OGR, and the BSR. 
Table 8. Average monthly dilute LLLW generation for 1989

\begin{tabular}{lcc}
\hline \multicolumn{1}{c}{ Generator } & $\begin{array}{c}\text { Monthly generation } \\
\text { (gal) }\end{array}$ & Percent of total \\
\hline Tank W-1A & 5,394 & 18 \\
Isotopes & & \\
HFIR & 5,232 & 17 \\
3039 stack area & 4,572 & 15 \\
Bldg. 3525 & 3,914 & 13 \\
Reactors & 3,004 & 10 \\
Bldg. 3517 & 2,405 & 8 \\
4500 complex & 1,337 & 4 \\
Bldg. 7920 & 1,302 & 4 \\
Tank WC-8 pump pit & 941 & 3 \\
PWTP spent acid & 816 & 3 \\
Bldg. 3019 & 620 & 2 \\
All others & 23 & $<1$ \\
Total & 1,064 & 3 \\
\hline
\end{tabular}

Isotopes include all collections from Isotopes Area collection tanks WC-10 and WC-2, Bidg. 3026C collection tanks W-17 and W-18, and Bldg. 3026D collection tank W-16.

${ }^{b}$ Reactors include the ORR, the OGR, and the BSR. 


\subsubsection{Isotopes Area}

The isotope facilities' primary tasks are producing, purifying, and distributing various radionuclides. A very wide range of radioisotopes is handled, and activities include tritium processing, ${ }^{85} \mathrm{Kr}$ separation, short-lived fission products processing, ${ }^{137} \mathrm{Cs}$ and ${ }^{90} \mathrm{Sr}$ source fabrication, ${ }^{60} \mathrm{Co}$ storage and irradiation, ${ }^{99} \mathrm{Tc}$ processing, and some transuranic isotope processing.

As seen in Table 4, LLLW collections from the Isotopes Area have accounted for 16\% (5061 gal/month) of the total LLLW collections since 1986. LLLW generation from the Isotopes Area decreased dramatically from 1986 (7466 gal/month) to 1987 (3779 gal/month), but since 1987 the level of LLLW generation has remained at -3800 gal/month. However, through the first half of 1989, LLLW generation increased to $5232 \mathrm{gal} /$ month because of above average rainfall (and therefore inleakage) into tanks W-17 and W-18. Collection tanks in the Isotopes Area include WC-2, WC-10, W-16, $\mathrm{W}-17$, and $\mathrm{W}-18$.

While the Isotopes Area is primarily production oriented, very little LLLW is generated as a direct result of processing activities. Most of the waste production is a result of routine and nonroutine hot cell decontamination. The primary nuclides expected to be in the waste strecms generated from these facilities are ${ }^{137} \mathrm{Cs},{ }^{90} \mathrm{Sr}$, and ${ }^{131}$ I. However, smaller quantities of many other nuclides can also be expected to be present in the waste stream. A list of these other nuclides and the estimated quantity of each is given in Table 9. Also presented in Table 9 is a list of the contaminants in the Isotopes Area waste stream and their respective estimated quantities.

\subsubsection{Stack Area}

Process off-gas streams generated within processes or R\&D equipment are vented to the COG collection system (3039 stack) for the removal of radioactive iodine. The off-gases potentially contain other radioactive species, flammable vapors, and toxic vapors. After collection, the gases are scrubbed with a $0.5 \%$ caustic $(\mathrm{NaOH})$ solution, passed through a high-efficiency particulate air (HEPA) filter, and then discharged. The scrubbing operation produces a spent caustic solution that is slightly contaminated. This caustic solution is transferred to the LLLW system for treatment. The 3039 stack 
Table 9. Annual LLLW stream components for the Isotopes Area

\begin{tabular}{|c|c|c|c|}
\hline Nuclide & $\begin{array}{c}\text { Annual } \\
\text { quantity (Ci) }\end{array}$ & Other stream component & $\begin{array}{c}\text { Annual } \\
\text { quantity } \\
(\mathrm{kg})^{a}\end{array}$ \\
\hline $\begin{array}{l}\text { Ag-110m } \\
\text { Am-241 } \\
\text { Am-243 } \\
\text { Cf-252 } \\
\text { Cm-244 } \\
\text { Co-56 } \\
\text { Co-60 } \\
\text { Cs-137 } \\
\text { Eu-152 } \\
\text { Eu-154 } \\
\text { Fe-55 } \\
\text { Fe-59 } \\
\text { Gd-153 } \\
\text { H-3 } \\
\text { I-125 } \\
\text { I-129 } \\
\text { Ir-192 } \\
\text { Mn-54 } \\
\text { Ni-63 } \\
\text { Pm-147 } \\
\text { Pu-238 } \\
\text { Pu-239 } \\
\text { Sr-90 } \\
\text { Tc-99 } \\
\text { U-234 } \\
\text { U-235 } \\
\text { W-188 }\end{array}$ & $\begin{array}{c}0.8 \\
\text { Trace } \\
\text { Trace } \\
\text { Trace } \\
\text { Trace } \\
\text { Trace } \\
3 \\
30 \\
\text { Trace } \\
\text { Trace } \\
\text { Trace } \\
\text { Trace } \\
\text { Trace } \\
1.2 \mathrm{E}-4 \\
1.2 \mathrm{E}-3 \\
3 \\
\text { Trace } \\
\text { Trace } \\
\text { Trace } \\
3 \\
\text { Trace } \\
\text { Trace } \\
30 \\
3 \\
\text { Trace } \\
\text { Trace } \\
1.2 \mathrm{E}-3\end{array}$ & $\begin{array}{l}\text { AHIB (organic acid) } \\
\text { Ammonium hydroxide } \\
\text { Citric acid } \\
\text { Hydrochloric acid } \\
\text { Methyl isobutyl ketone } \\
\text { Nitric acid } \\
\text { Oxalic acid } \\
\text { Potassium hydroxide } \\
\text { Potassium permanganate } \\
\text { Sodium hydroxide } \\
\text { Sulfurous acid } \\
\text { Detergents }\end{array}$ & $\begin{array}{c}1 \\
2 \\
11 \\
2 \\
1 \\
104 \\
33 \\
2 \\
27 \\
4 \\
90 \\
210\end{array}$ \\
\hline
\end{tabular}

"For purposes of this report, "other stream component" quantities are considered to be $1 \mathrm{~kg}$ when estimated quantities are less than $1 \mathrm{~kg}$. All others are rounded to the nearest kilogram. 
area produces -3600 gal per month of dilute LLLW, which accounts for $-11 \%$ of the total volume of dilute LLLW collected since 1986.

Past sampling data show that the LLLW stream produced at the 3039 stack area is quite dilute. Assuming that the LLLW evaporator concentrates the dilute LLLW to a specific gravity of $1.25 \mathrm{~g} / \mathrm{mL}$, this stream contributes <50 gal/month to the LLLW concentrate stream.

\subsubsection{High Flux Isotopes Reactor}

LLLW collected from the HFIR is geverated primarily from the following sources: (1) regeneration and backwashing of primary and pool demineralization systems, (2) waste from sampling, (3) head tank overflow, (4) gaseous waste filter pit, (5) 7911 stack drainage, and (6) the off-gas condensate collection pit. ${ }^{1}$ An analysis of the primary demineralizer LLLW stream is summarized by Pretez ${ }^{2}$ The LLLW generation rate in 1986 was -5370 gal/month. Since the HFIR shut down, the LLLW generation rate has fallen to $-280 \mathrm{gal} /$ month. The restart of HFIR in 1989 has increased the LLLW generation to $-4600 \mathrm{gal} / \mathrm{month}$ at that facility.

The most significant LLLW generation source at HFIR is the regeneration and backwashing of the primary and pool demineralization systems. These regeneration solutions account for $\sim 20,000 \mathrm{gal}$ of dilute LLLW annually and also represent the primary source of ${ }^{60} \mathrm{Co}$ at ORNL.'

\subsubsection{Oak Ridge Reactor/Bulk Shielding Reactor/Old Graphite Reactor}

The ORR was shut down permanently in 1987 and will not be restarted. Current and future LLLW generated at the ORR is the result of decontamination and decommissioning activities, as well as regeneration of the demineralizer columns. Similarly, ongoing maintenance and decommissioning activities require the regeneration of demineralizers at the OGR.

The BSR is expected to continue operation. Sources of LLLW from the BSR are cooling water and ion-exchange column spent regeneration solutions.

The monthly LLLW generation from these facilities has averaged $-3200 \mathrm{gal} / \mathrm{month}$ since 1986, falling from a level of $5500 \mathrm{gal} /$ month in 1986 to a level of -1400 
gal/month in 1988. Much of the decrease is due to the shutdown of the ORR and relatively light rainfall in 1987 and 1988 . With increased rainfall during the first half of 1989 , generation rates have increased to $2400 \mathrm{gal} /$ month. More discussion pertaining to the influence of rainfall into collection tank WC-19 will follow in

Sect. 4.2.

The LLLW stream from each of these facilities can be described as a stream primarily resulting from the regeneration of demineralizer systems. As such, each of the individual waste streams comprise weak acid and base solutions. It is estimated that a total of $460 \mathrm{gal}$ of $5 \%$ nitric acid, $110 \mathrm{gal}$ of $5 \%$ sulfuric acid, and $575 \mathrm{gal}$ of $5 \%$ sodium hydroxide are expended annually by these facilities. The total waste stream from these facilities is also estimated to contain as much as $3 \mathrm{Ci}$ /year ${ }^{106} \mathrm{Ru}$ and trace amounts of such nuclides as ${ }^{60} \mathrm{Co},{ }^{137} \mathrm{Cs},{ }^{54} \mathrm{Mn},{ }^{206} \mathrm{Ra}$, and ${ }^{90} \mathrm{Sr}$.

\subsubsection{Fission Products Development Laboratory}

The FPDL (Bldg. 3517) processes large quantities of ${ }^{137} \mathrm{Cs}(-350,000 \mathrm{Ci} /$ year) and ${ }^{90} \mathrm{Sr}(\sim 500,000 \mathrm{Ci} / \mathrm{year})$. Other materials that are occasionally processed at Bldg. 3517 are ${ }^{60} \mathrm{Co}$ and ${ }^{192} \mathrm{Ir}$. Materials that have been handled in the past include ${ }^{144} \mathrm{Ce}$ and ${ }^{147} \mathrm{Pm}$.

Building 3517 is the primary source of both cesium and strontium in the LLLW system. Estimated losses of each material are on the order of 5,000-15,000 Ci/year. The building activities that produce LLLW are not directly related to isotope processing but are derived primarily from routine decontamination of the hot cells used in cesium and strontium purification. In addition to the nuclides released to the LLLW system, this routine decontamination also results in the addition of $16 M$ nitric acid ( 500 gal/year), oxalic acid ( $500 \mathrm{lb} / \mathrm{year}$ ), $50 \%$ sodium hydroxide (300 lb/year), Turco Decon 4502 (500 lb/year), and various detergents to the LLLW system.

The LLLW production since 1986 has averaged $\sim 3100 \mathrm{gal} / \mathrm{month}$, but the level has decreased substantially during the time period from 1986 to 1989 . In fact, the LLLW production rate in 1986 was $-4600 \mathrm{gal} /$ month, and by 1988 that production rate had fallen to $3150 \mathrm{gal} /$ month. Shutdown of the facility in early 1989 has resulted in even smaller volumes of LLLW (1337 gal/mon) being sent to the LLLW system thus far in 1989. Recently, improvements have been made to the building's underground 
tank vault, which has reduced groundwater inleakage, and consequently the LLLW generation rates are expected to decrease even further.

\subsubsection{High Radiation Level Examination Laboratory}

The High Radiation Level Examination Laboratory (HRLEL) (Bldg. 3525) primarily serves as an area where irradiated metallurgical specimens can be examined. The area possesses both hot cells and storage wells for containment of radioactive materials. Currently, the facility is expected to handle a variety of radionuclides, including ${ }^{137} \mathrm{Cs}$, and uranium, plutonium, and thorium isotopes. It is estimated that 50 Cifyear of ${ }^{137} \mathrm{Cs}$ and trace quantities of the various uranium, plutonium, and thorium isotopes escape to the LLLW system via collection and transfer tank W-12. As is the case for other isotope areas, LLLW in this facility is mainly generated as a result of routine decontamination. In addition to the above-mentioned isotopes, sulfurous acid (450 lb/year), 15M sodium hydroxide (5 gal/year), $5 M$ nitric acid (5 gal/year), and detergents used in decontamination activities contribute to the LLLW.

The average monthly LLLW generation rate since 1986 has been $-2600 \mathrm{gal}$. The LLLW generation rate decreased from a 1986 generation rate of $3770 \mathrm{gal} /$ month to a rate of $1850 \mathrm{gal} /$ month in 1988 . In 1989, the LLLW generation rate increased as expected to $-3000 \mathrm{gal} / \mathrm{month}$ because of nonroutine hot cell revitalization/ decontamination activities.

\subsubsection{Complex}

The 4500 complex (Bldgs. 4500N, 4500S, 4501, 4505, 4507, and 4508) is a multipurpose research facility. There is a large variation in the radioactive materials that are handled in the complex, and small quantities of any radionuclide that is used at the laboratory could be disposed of from one of many active hot drains in the facility. There are approximately 89 active hot drains in the 4500 complex, each draining to one of four collection tanks (WC-11, WC-12, WC-13, and WC-14).

The 4500 complex has historically accounted for between 7 and $8 \%$ of all dilute LLLW collected at ORNL. Since 1986, the average LLLW generation rate has been 
-2600 $\mathrm{gal} /$ month. As seen in Tables 5-8, however, the monthly LLLW generation rate has decreased from $-5110 \mathrm{gal} /$ month in 1986 to only $1300 \mathrm{gal} / \mathrm{month}$ for the first 6 months in 1989.

As previously mentioned, small quantities of many radionuclides could be expected to be present in the 4500 complex waste stream. A summary of these nuclides and their estimated quantities is given in Table 10. As to be expected with a multipurpose research facility, the $\mathbf{4 5 0 0}$ area also releases small amounts of common acids, bases, detergents, and other chemical agents used in various laboratory procedures to the LLLW system. A list of these other LLLW stream components is provided in Table 10 as well.

\subsubsection{Radiochemical Engineering Development Center}

The REDC recovers a variety of radiochemicals produced by irradiation of selected targets. The REDC has consistently produced $-1400 \mathrm{gal} /$ month of $\mathrm{LLLW}$ since 1986. The LLLW is primarily generated from disposal of spent off-gas scrubber solutions. The scrubber solutions are typically of low activity. Small volumes of waste are generated as a direct result of isotope processing from operations conducted at the REDC facility. These wastes are sent to the LLLW system and are a major contributor to the transuranic and fission product isotopes that are collected in the system. Table 11 summarizes the radioactive and nonradioactive components that are released to the LLLW system from the REDC.

\subsubsection{Overall System Collection Rates}

Table 12 summarizes the total LLLW collections from all generators for years 1986 through 1989 . As of 1988 , the LLLW collections had declined by $-44 \%$ since 1986. With the exception of LLLW generations from the REDC facility and the 3039 stack area, all generators seem to have substantially decreased their LLLW generation rates. The reason for this decline is in part the result of waste reduction programs spurred by institution of a charge-back plan started at ORNL in 1986. Other factors influencing the decline in LLLW generation are the lower yearly rainfalls since 1986, the shutdown in 1986 of the HFIR, decommissioning of the ORR, and improvements 
Table 10. Annual LLLW stream components for the 4500 complex

\begin{tabular}{|c|c|c|c|}
\hline Nuclide & $\begin{array}{c}\text { Annual } \\
\text { quantity } \\
\text { (Ci) }\end{array}$ & $\begin{array}{l}\text { Other stream } \\
\text { component }\end{array}$ & $\begin{array}{c}\text { Annual } \\
\text { quantity } \\
(\mathbf{k g})^{a}\end{array}$ \\
\hline $\begin{array}{c}\text { Am-241 } \\
\text { Am-243 } \\
\text { C-14 } \\
\text { Co-58 } \\
\text { Co-60 } \\
\text { Cs-134 } \\
\text { Cs-137 } \\
\text { Eu-152 } \\
\text { Eu-154 } \\
\text { Fe-59 } \\
\text { H-3 } \\
\text { Mn-54 } \\
\text { Pu-238 } \\
\text { Pu-239 } \\
\text { Pu-242 } \\
\text { Ra-226 } \\
\text { Sr-89 } \\
\text { Sr-90 } \\
\text { Tc-95m } \\
\text { Tc-99 } \\
\text { Th-232 } \\
\text { U-233 } \\
\text { U-238 }\end{array}$ & $\begin{array}{c}\text { Trace } \\
\text { Trace } \\
\text { Trace } \\
\text { Trace } \\
1.1 \mathrm{E}-2 \\
6.0 \mathrm{E}-2 \\
0.7 \\
\text { Trace } \\
\text { Trace } \\
\text { Trace } \\
1.2 \mathrm{E}-4 \\
\text { Trace } \\
\text { Trace } \\
\text { Trace } \\
\text { Trace } \\
\text { Trace } \\
\text { Trace } \\
\text { Trace } \\
\text { Trace } \\
\text { Trace } \\
2.2 \mathrm{E}-6 \\
\text { Trace } \\
3.4 \mathrm{E}-5\end{array}$ & $\begin{array}{l}\text { Ammonium hydroxide } \\
\text { Hydrochloric acid } \\
\text { Methanol } \\
\text { Nitric acid } \\
\text { Sodium hydroxide } \\
\text { Sulfuric acid } \\
\text { Detergents } \\
\text { Acetone } \\
\text { Hydrofluoric acid } \\
\text { Potassium dichromate }\end{array}$ & $\begin{array}{c}1 \\
1 \\
1 \\
50 \\
1 \\
2 \\
4 \\
4 \\
1 \\
50\end{array}$ \\
\hline
\end{tabular}

For purposes of this report, "other stream component" quantities are considered to be $1 \mathrm{~kg}$ when estimated quantities are less than $1 \mathrm{~kg}$. All others are rounded to the nearest kilogram.

in the operation of the PWTP. One result that can be gleaned from study of the data in Table 12 is that projected LLLW collections in 1989 are about $14 \%$ greater than the actual collections in 1988. This increase in LLLW collections may be because of increased fugitive inleakage related to higher rainfall levels to date in 1989 (1.6 in./week average) compared to that in 1988 (0.83 in./week); however, the absolute amount of the LLLW generation increase that can be attributed to increased rainfall in 1989 is uncertain. Rainfall infiltration into the LLLW CAT System is covered in more detail in the next section. 
Table 11. Annual LILW stream compouents for the REDC

\begin{tabular}{lc|lc}
\hline \multicolumn{1}{c||}{ Nuclide } & $\begin{array}{c}\text { Annual } \\
\text { quantity } \\
(\mathrm{Ci})\end{array}$ & Other stream component & $\begin{array}{c}\text { Annual } \\
\text { quantity } \\
(\mathrm{kg})^{\circ}\end{array}$ \\
\hline Am-241 & 1.7 & Acidified butyrates & 1 \\
Am-242 & Trace & Adogen-hydrochloric acid & 24 \\
Am-243 & 0.1 & AMSCO (petroleum & 768 \\
Cf-252 & 0.8 & naphtha) & 1 \\
Cm-244 & 78.2 & 2,5-Dibutylhydroquinone & 24 \\
Cm-246 & 0.2 & Diisoprophylbenzene & 48 \\
Mixed fission products & 42,000 & (DIPB) & 151 \\
Mixed plutonium & 0.5 & 2-Ethylhexanol & 146 \\
Other califormium & Trace & HDEHP extractant & 123 \\
Other curium & Trace & Hydrochloric acid & 1 \\
& & Lithium chloride & 3 \\
& & Lithium nitrate & 1 \\
& & Mercury (II) nitrate & 9686 \\
& & Nitric acid & 2089 \\
& & Potassium carbonate & 115 \\
& & Potassium hydroxide & 284 \\
& & Sodium aluminate & 1 \\
& & Sodium hydroxide & \\
& & Sodium thiosulfate & \\
\hline
\end{tabular}

"For purposes of this report, "other stream component" quantities are considered to be $1 \mathrm{~kg}$ when estimated quantities are less than $1 \mathrm{~kg}$. All others are rounded to the nearest kilogram.

Table 12 Summary of annual LLLW production rates

\begin{tabular}{ccc}
\hline Year & $\begin{array}{c}\text { LLLW generation } \\
(\mathrm{gal})\end{array}$ & $\begin{array}{c}\text { Change from } \\
\text { previous year (\%) }\end{array}$ \\
\hline 1986 & 517,505 & \\
1987 & 328,638 & -36.5 \\
1988 & 288,961 & -12.0 \\
$1989^{\circ}$ & 329,243 & 13.9 \\
\hline
\end{tabular}

a1989 LLLW generation rate is projected from actual LLLW collections as of June 1989. 


\section{RAINFALL INLEAKAGE INTO THE LLLW SYSTEM}

Inleakage of rainfall into the LLLW system has been qualitatively recognized for some time; however, a quantitative estimate of the effects of rainfall on the volume of LLLW collected at ORNL has not been made. It was the objective of this work to derive a quantitative relationship between rainfall levels and LLLW collections and to determine which of the tanks in the LLLW system were affected by rainfall and to what extent. The data necessary to perform this analysis, the weekly LLLW generation rates and weekly rainfall amounts, were obtained from the Liquid and Gaseous Waste Operations Group of the E\&HP Division and from the Plant and Equipment Division respectively.

A plot of LLLW collections as a function of rainfall is shown in Fig. 7. It is obvious from Fig. 7 that there is a high degree of scatter to the data. However, if the rainfall data are plotted in a time-ordered plot with LLLW collections as in Fig. 8, there appears to be a relationship between weekly rainfall and weekly LLLW collection rates. Therefore, it was determined that a time series analysis was an appropriate approach to determine which tanks were, in fact, collecting rainwater and to derive a rough estimate of how much LLLW is created by a given amount of rain.

The time series analysis identified LLLW collections in the following tanks to be significantly influenced by rainfall: WC-19, W-1A, WC-11, WC-12, Bldg. 3517 tanks, WC-8, WC-5 and -6, and WC-17 and -18. A very approximate estimate of LLLW collected (in gallons) from each of these tanks per inch of rainfall is $223,644,93,30$, 138, 47, 28, and 260 respectively. These data imply that for each inch of rainfall, there are $-1500 \mathrm{gal}$ of LLLW collected from the above tanks. It must be emphasized that all of these projections of LLLW generation as a function of rainfall are only approximations, and care must be taken when interpreting these results.

\section{CONCENTRATE GENERATION}

LLLW concentrate is the resulting evaporator bottoms when the dilute LLLW is evaporated. The condensate liquid is sent to the PWTP for further treatment. Hydrofracture was used as a means of disposing of LLLW concentrate for several years 


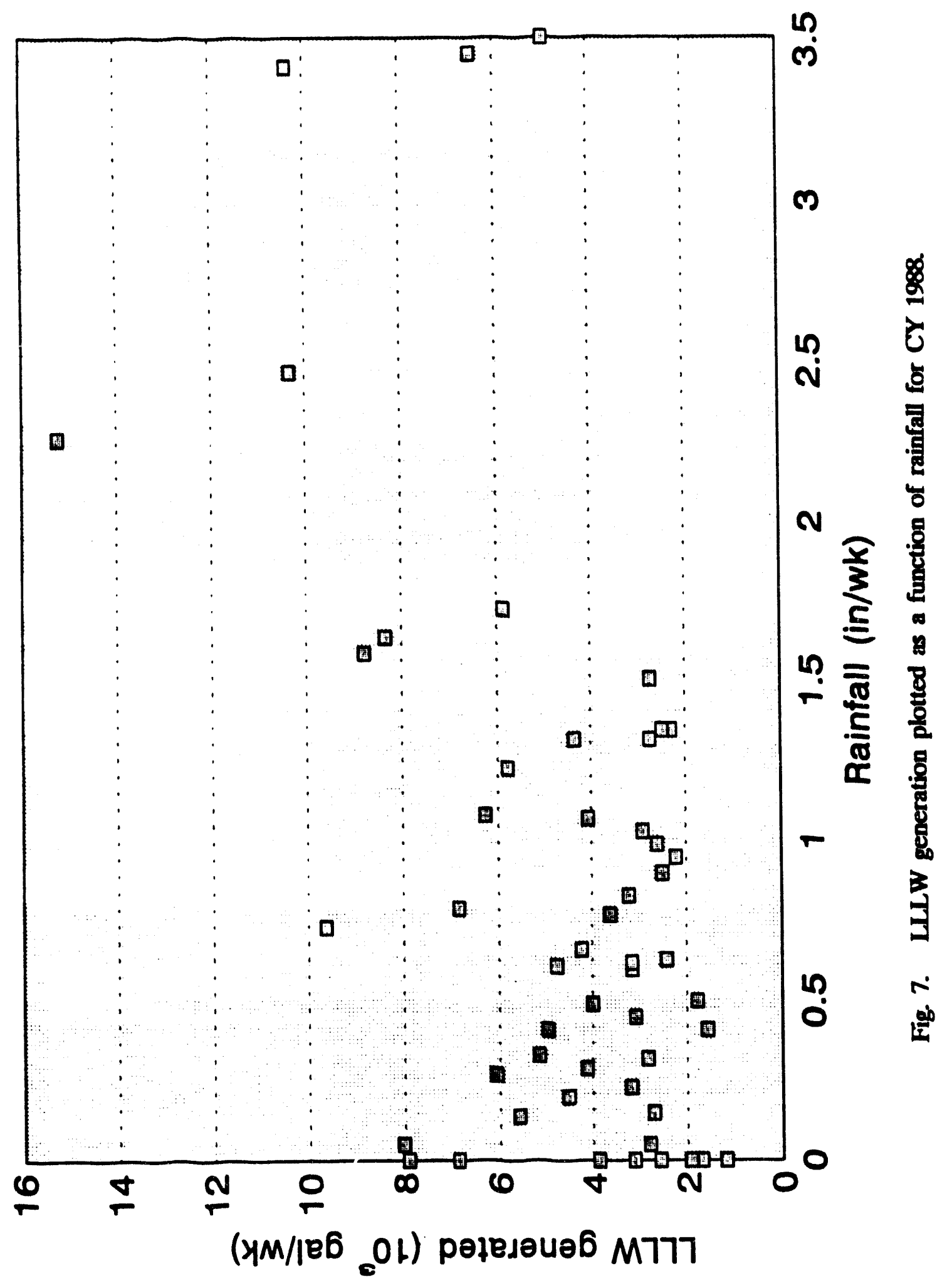




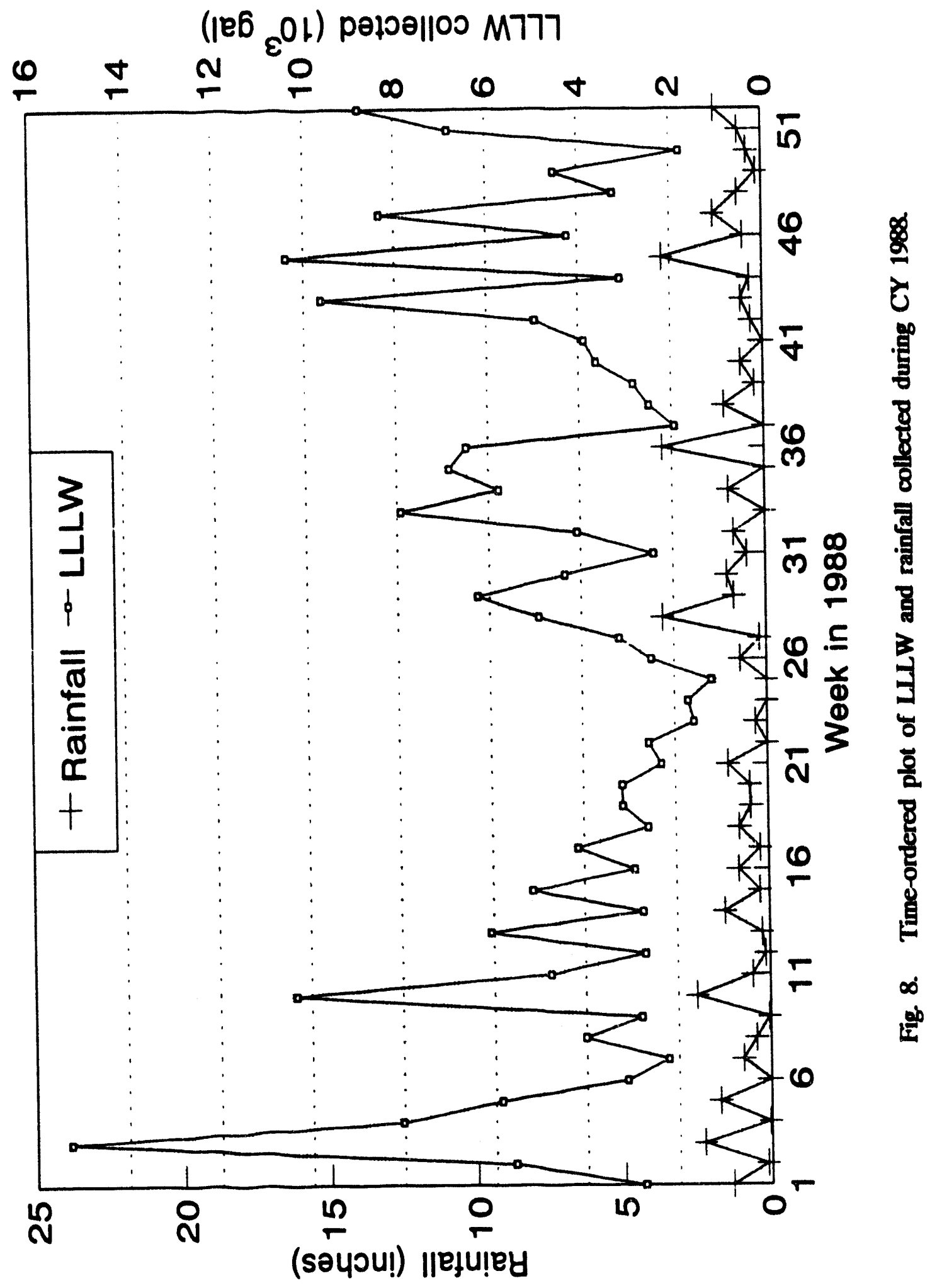


in the early 1980 s but was discontinued and is no longer considered a viable disposal option. Currently, LLLW concentrate is being accumulated and stored. The capacities of the storage tanks and the LLLW concentrate volumes as of mid-1989 are shown in Table 13.

Figure 9 shows the decrease of available storage space for LLLW concentrate since 1986. The decrease in cumulative concentrate stored during 1988 is the result of the Emergency Avoidance Solidification Campaign (EASC) freeing about 47,000 gal of tank space. In the EASC this LLLW concentrate was solidified in a grout mixture, and the solid waste forms are now in interim storage. The EASC is discussed in detail in Sect. 5.1.

The rate of concentrate generation per year since 1986 is seen in Table 14. The concentrate generation rate is expected to increase in the next several years for the following facilities and programs: (1) decontamination of facilities and hot cells,

(2) Remedial Action Programs' decommissioning and decontamination of inactive tanks, and (3) the HFIR restart.

\subsection{SOLDIFICATION OF LLLW CONCENTRATE}

The first solidification campaign, the EASC, in which $47,000 \mathrm{gal}$ of LLLW concentrate were immobilized in a cement-based matrix, was completed at the end of CY 1988. The solidification was done by L\&N Technologies, a contracted vendor. L\&N proposed a grout mixture that, when solidified with the LLLW supernatant from MVSTs W-29 and W-30, would pass the leachability tests. They provided the grout mixture, the equipment necessary to mix the LLLW with the grout mixture, and thepersonnel who performed the solidification. Once the waste was solidified, the forms were placed in interim storage on an open concrete diked pad in the Melton Valley area. 
Table 13. Liquid low-ievel waste concentrate tank volumes and capacities

\begin{tabular}{lcc}
\hline Tank & Capacity (gal) & $\begin{array}{c}\text { Volume of waste } \\
(\mathrm{gal})^{a}\end{array}$ \\
\hline C-1 & 50,000 & 10,140 \\
C-2 & 50,000 & 45,260 \\
W-21 & 50,000 & 16,570 \\
W-23 & 50,000 & 34,020 \\
W-24 & 50,000 & 44,510 \\
W-25 & 50,000 & 30,400 \\
W-26 & 50,000 & 33,860 \\
W-27 & 50,000 & 45,640 \\
W-28 & 50,000 & 46,330 \\
W-29 & 50,000 & 46,870 \\
W-30 & 50,000 & 46,830 \\
W-31 & 50,000 & 46,610 \\
Total & & 447,040 \\
\hline
\end{tabular}

¿Liquid low-level waste concentrate volumes are as of June 1, 1989.

\section{N-TANK EVAPORATION}

A procedure known as in-tank evaporation (ITE) will be performed on the MVSTs to reduce the amount of liquid waste stored. Each of the eight storage tanks has a tank ventilation system for purging gases from the tanks, as well as submersed air sparges used to mix the contents of the tanks. In the ITE schema, unsaturated (or possibly dry) air will be introduced into the tanks and will theoretically leave the tanks saturated with water. Several studies have been completed to determine the viability of ITE and its effect on the availability of storage volumes. ${ }^{3}$ As determined by these studies, ITE will free -3000 gal/year per tank. This rate was based on the following assumptions: (1) $80 \%$ on-line time for the operation, (2) saturation temperature of $50^{\circ} \mathrm{F}$, (3) bone-dry input air to the tanks, and (4) $100 \%$ saturated outlet air. At a 


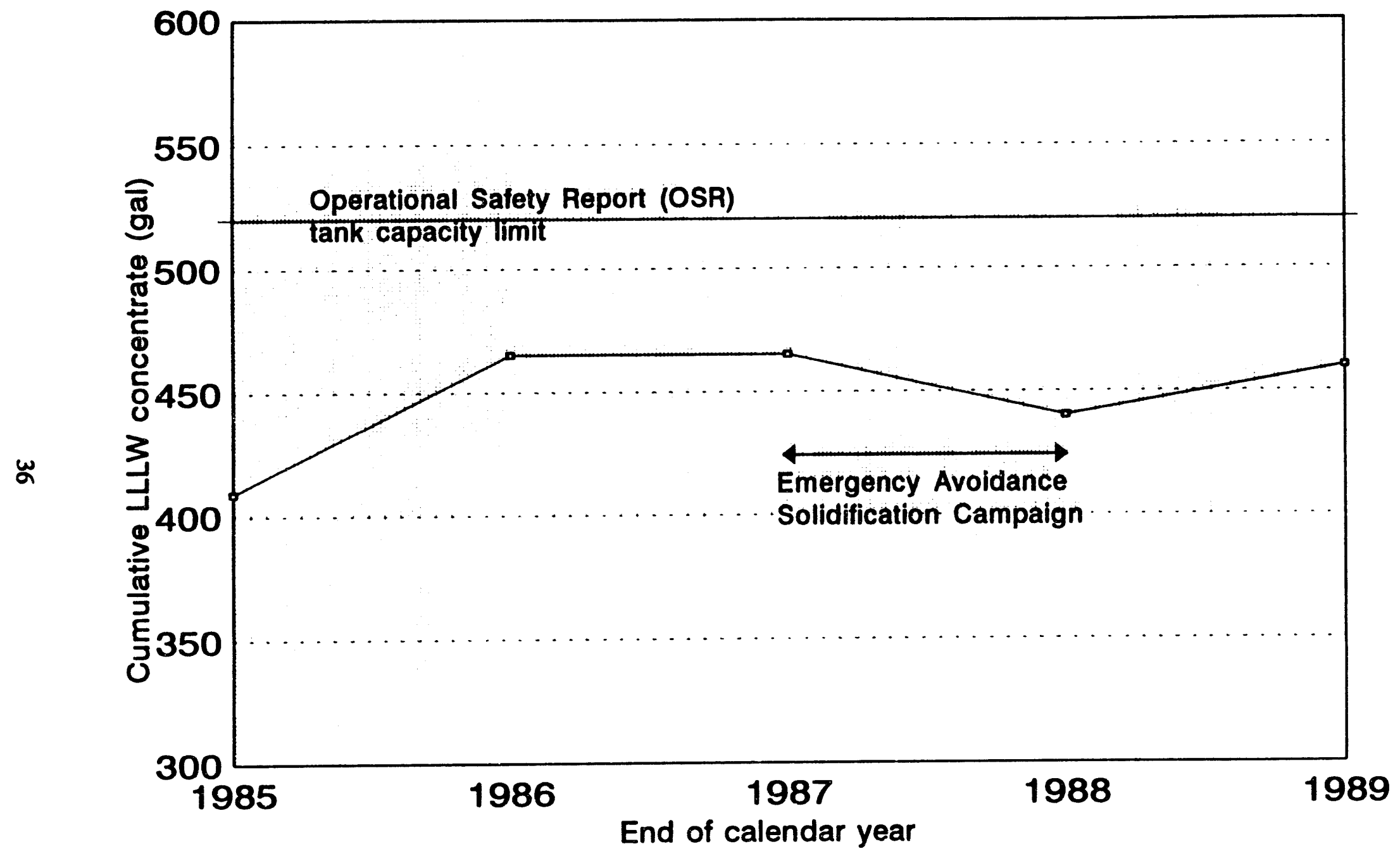

Fig. 9. LLLW concentrate storage volume occupied over time period 1985-1989. 
saturation temperature of $90^{\circ} \mathrm{F}$, this liquid evaporation rate increases to about 10,000 gal/year per tank with the same assumptions. ${ }^{3}$

ITE is scheduled to begin in FY 1990. Various stages of development work will be implemented, and full-scale evaporation will not occur until about 1 year later. This evaporation process is expected to continue until the supernates in the tanks reach saturation of sodium nitrate.

Table 14. LULW concentrate generation, 1986-1990

\begin{tabular}{cc} 
Year & $\begin{array}{c}\text { LLLW concentrate } \\
\text { generation (gal) }\end{array}$ \\
1986 & 34,132 \\
1987 & 22,036 \\
1988 & 26,863 \\
1989 & 10,059 \\
1990 & 16,140 \\
\hline
\end{tabular}

\subsection{LLWW CONCENTRATE GENERATION}

Quantities of LLLW concentrate generated over the last several years are given in Table 14. The generation rates have decreased steadily since 1986 . The major contributing factor in the decrease of LLLW concentrate generation is thought to be the implementation of the charge-back system, where the generators were charged for their disposal of dilute LLLW. An awareness of waste generation as well as an attempt to reduce unnecessary waste generation resulted from the charge-back program. The program has since been terminated, with new programs emphasizing waste reduction at various facilities being implemented. 


\section{LLLW SYSTEM PERFORMANCE}

LLLW is collected by the LLLW CAT System, transferred to the evaporator feed tank (W-22), and fed semibatchwise to the LLLW evaporator as necessary to maintain adequate LLLW collection system capacity. The concentrate produced in each evaporator run or campaign is then transferred to one of several LLLW concentrate storage tanks in the evaporator complex and eventually transferred to the MVSTs. A description of the evaporation process was reviewed in Chap. 2.

While the LLLW evaporator is run according to a standardized procedure, the volume reduction efficiency of each evaporator batch varies dramatically. The volume reduction factor (VRF) is defined as the ratio of dilute LLLW fed to the evaporator to the concentrated LLLW produced from an evaporator campaign. The objectives of this study are (1) to determine which waste streams are the primary volume contributors to the LLLW concentrate (which will allow a prediction of the variability of the evaporator performance as a function of the LLLW collections from specific generators), (2) to explore the contributions of operational variability on the performance of the LLLW evaporator, and (3) to explore possible errors in the monitoring of dilute and concentrated LLLW inventories.

\subsection{DATA SOURCES AND COLLECTION}

The LLLW evaporator performance was analyzed using generator, evaporator feed, and concentrate production data specific to each evaporator batch or campaign. Data quantifying the specific LLLW feed sent to the evaporator complex (Building 2531) for each LLLW evaporator campaign were gathered from the monthly LLLW Collection Tank Inventory and Transfers log sheets, Service Tank Balance Sheets, and a monthly summary of evaporaior feeds and products collected by the Gaseous and Liquid Waste Operations Group in the E\&HP Division. Data quantifying the concentrate produced from each LLLW evaporator campaign were extracted from the Service Tank Balance Sheets and a monthly summary of evaporator feeds and products. The LLLW collection volume information reported by the Waste Operations Group is calculated from the daily changes in the level of each LLLW collection and iransfer 
tank, evaporator service tank, and each MVST. Although the accuracy of each of the tank level detectors cannot be quantified, it is generally understood that the accuracy of the level detectors is quite good, and thus errors in tracking the dilute and concentrated LLLW inventories cannot account for a large variability in the VRF. The following section will explore the possible effects of varying feed characteristics and operational variability on the VRF.

\subsection{DATA ANALYSIS}

The data in Table 15 summarize the dilute LLLW fed to each of the LLLW evaporators from tank W-22, the concentrate production, and the VRF for each evaporator campaign from 1986 through 1988. The large variability in the VRF from different evaporator campaigns can be readily observed from Table 15 . In fact, over the 3-year period from January 1986 to December 1988, the VRF of each evaporator batch varied from a low of 5.3 to a high of 43.8 . The reasons for the variability in evaporator performance are most likely twofold: (1) the different characteristics of wastes routinely collected from individual generators vary in radionuclide and inorganic salt concentrations, causing varying degrees of volume reduction efficiencies for specific waste streams, and (2) the operation of the LLLW evaporator experienced variability.

\subsection{Relationship Between VRF and LLLW Collections from Specific Generators}

A stepwise regression program of SAS was used to analyze the evaporator campaign data. The purpose of the analysis was to determine which generators, if any, were primarily responsible for LLLW concentrate production.

A linear model that relates LLLW generation from specific generators to LLLW concentrate production is

$$
\sum x_{i} a_{i}=\frac{1}{V R F}
$$

where $x_{i}$ is the volume fraction of the waste or rainfall collected from each LLLW generator or the amount of rainfall collected for a given evaporator campaign, $a_{i}$ is a 
Table 15. LLLW evaporator data, 1986-1988

\begin{tabular}{|c|c|c|c|c|c|}
\hline \multirow{2}{*}{$\begin{array}{l}\text { Evaporator } \\
\text { campaign dates }\end{array}$} & \multicolumn{2}{|c|}{$\begin{array}{l}\text { LLLW sent to } \\
\text { evaporators (gal) }\end{array}$} & \multicolumn{2}{|c|}{$\begin{array}{l}\text { Concentrated LLLW } \\
\text { generated (gal) }\end{array}$} & \multirow{2}{*}{ VRF } \\
\hline & $2 A 2$ & A1 & $2 A 2$ & A2 & \\
\hline \multicolumn{6}{|l|}{1986} \\
\hline$\overline{02 / 25}-05 / 19$ & 37,549 & 60,438 & 1183 & 5012 & 15.8 \\
\hline 05/19-08/14 & 76,565 & 54,054 & 3108 & 2484 & 23.4 \\
\hline $11 / 03-11 / 22$ & 39,841 & & 1396 & & 28.5 \\
\hline $11 / 20-12 / 09$ & 48,080 & & 1122 & & 42.9 \\
\hline $12 / 08-01 / 17 / 87$ & 51,737 & 11,463 & 1296 & 1760 & 20.7 \\
\hline 1986 overall & & & & & 25.2 \\
\hline \multicolumn{6}{|l|}{1987} \\
\hline $01 / 16-01 / 30$ & 32,937 & & 1987 & & 16.6 \\
\hline $01 / 30-02 / 17$ & 29,291 & & 1978 & & 14.8 \\
\hline $02 / 16-02 / 28$ & 19,974 & & 2101 & & 9.5 \\
\hline $02 / 28-03 / 29$ & 38,996 & & 1664 & & 23.4 \\
\hline 03/23-06/09 & 58,267 & & 2100 & & 27.8 \\
\hline 06/09-07/05 & 28,630 & & 2553 & & 11.2 \\
\hline $06 / 22-08 / 24$ & 43,243 & & 1260 & & 34.3 \\
\hline $08 / 13-10 / 30$ & 73,760 & & 1690 & & 43.6 \\
\hline $10 / 30-01 / 17 / 88$ & 58,118 & & 1940 & & 30.0 \\
\hline 1987 overall & & & & & 222 \\
\hline \multicolumn{6}{|l|}{1988} \\
\hline $01 / 17-02 / 06$ & 43,496 & & 2708 & & 16.1 \\
\hline 02/04-03/07 & 13,428 & & 2528 & & 5.3 \\
\hline 03/03-04/06 & 49,667 & & 1396 & & 35.6 \\
\hline 04/05-06/25 & 39,403 & & 1377 & & 28.6 \\
\hline 06/25-08/05 & 33,258 & & 2730 & & 12.2 \\
\hline $08 / 01-09 / 16$ & 19,924 & & 3166 & & 6.3 \\
\hline $09 / 05-11 / 10$ & 1,279 & 50,172 & & 1710 & 30.1 \\
\hline $11 / 07-12 / 01$ & & 35,970 & & 1560 & 23.1 \\
\hline 1988 overall & & & & & 16.7 \\
\hline
\end{tabular}


constant which represents the amount of concentrate produced from the volume of dilute LLLW collected from each generator or unit of rainfall during the campaign, and $V R F$ represents the volume reduction factor of each campaign.

The regression analysis provided the following model:

$$
\frac{1}{V R F}=1.87 v f_{3544}+0.14 v f_{3517}
$$

with

$$
\text { R-squared }=0.77 \text {, }
$$

where $v f_{354}$ is the volume fraction of the PWTP ion-exchange eluate sent to the LLLW system for evaporation and $v f_{3517}$ is the volume fraction of waste from the FPDL present in the dilute LLLW fed to the evaporator in a given evaporator campaign respectively.

The model demonstrates that of the many generators listed in Table 4 only the LLLW collected from two areas, the PWTP and the FPDL, contributes significantly (at a $90 \%$ confidence limit) to the LLLW concentrate production. The volumes from all other sources, including contribution from rainfall, had no significant effect on concentrate production in the presence of these facilities' generations. It must be noted, however, that this regression analysis only accounts for $77 \%$ of the variability present in concentrate production from each campaign and consequently does not comprise a model of the system that alone would be adequate for LLLW system simulation or could accurately predict concentrate production.

\subsection{Operational Variability}

Operational variability also appears to have a significant effect on the volume reduction efficiency of the LLLW evaporator. Figure 10 shows the relationship between the VRF and the amount of dilute LLLW fed to the evaporator in a given campaign. These data are summarized in Table 16. As can be discerned from Fig. 10, as a greater volume of dilute LLLW is processed through the evaporator in a given campaign, the VRF for that campaign is increased dramatically. In fact, the observed VRFs vary from a low of -5.3 when $13,428 \mathrm{gal}$ of dilute LLLW is processed in a campaign to a high of 43.6 when $73,760 \mathrm{gal}$ of dilute LLLW are fed. 


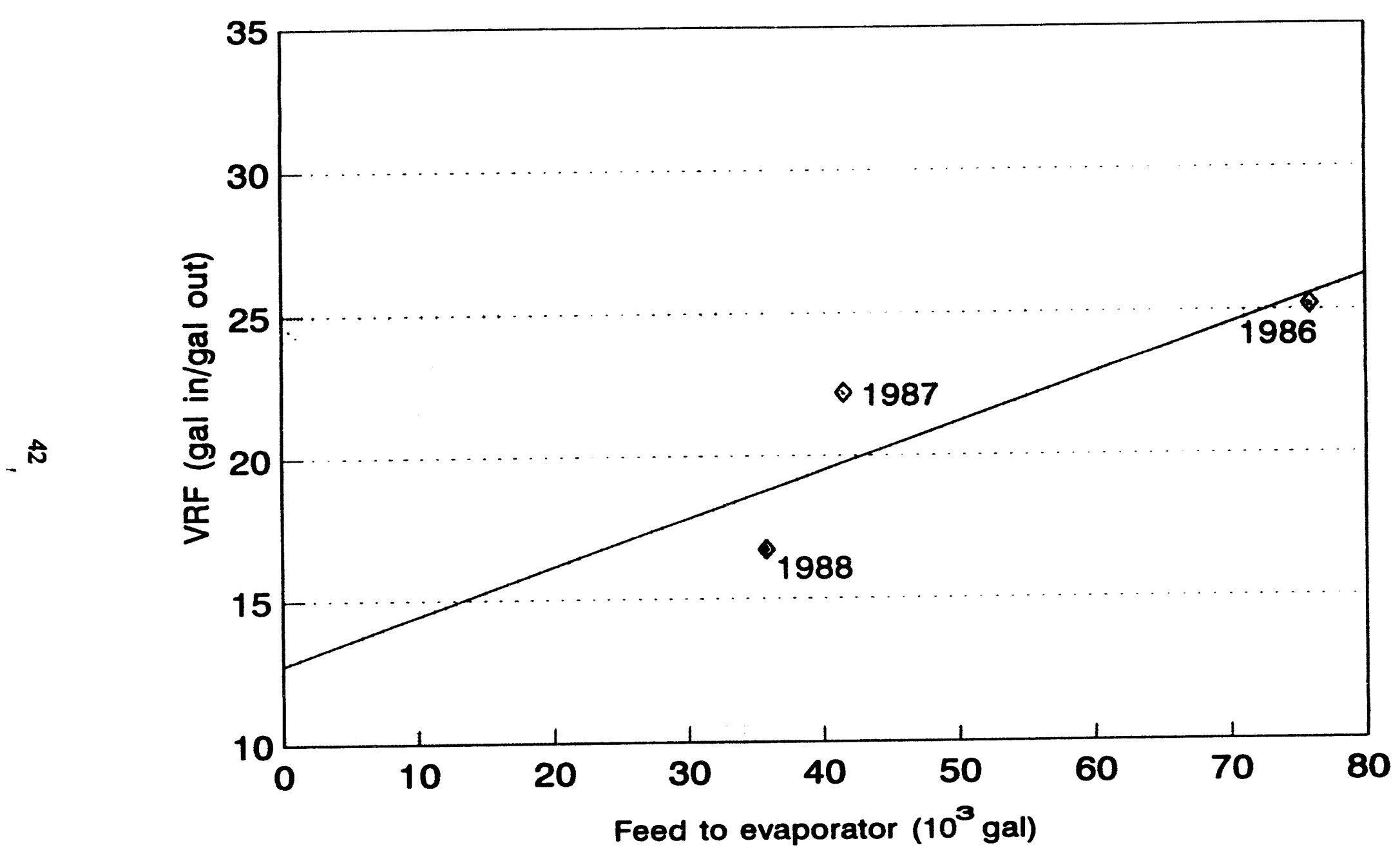

Fig. 10. Volume reduction factor (VRF) as a function of dilute LLLW fed to the evaporator. 
As was mentioned earlier, the operating procedure for the LLLW evaporator calls for the evaporator to be run until the specific gravity of the LLLW concentrate reaches a value of $\sim 1.25$. Also, the evaporator procedure specifies that the evaporator operate at a constant level. The operating data indicate that both of these specifications cannot necessarily be met concurrently. A certain amount of dilute LLLW feed must be available to process through the evaporator in a given campaign to allow concentration to a specific gravity of 1.25 while maintaining a safe operating level in the LLLW evaporator. If an insufficient amount of feed is available, then the evaporator is run according to evaporator level, and the specific gravity target is not met. In these instances, the volume reduction efficiency for that campaign is decreased.

Over the past 3 years, the LLLW evaporator batch sizes have, on average, decreased. Figure 11 shows that since 1986 the average size of an evaporator batch fell from $\sim 75,000 \mathrm{gal}$ to slightly under $40,000 \mathrm{gal}$ in 1988 . Consequently, the average volume reduction factor fell from -25 in 1986 to $\sim 16$ in 1988.

\section{RESULTS}

There are two major sources of VRF variability in the operation of the LLLW evaporator: (1) variability in the source of the feed of each evaporator batch and (2) variability in the operation of the evaporator itself. As was demonstrated in Sect. 6.2.1, only two facilities, the FPDL and the PWTP, are most important statistically as LLLW concentrate generators. Thus, these two generators need to be targeted as areas for future sampling campaigns to characterize their waste.

After the wastes are characterized, the potential for source treatment needs to be determined. The potential savings of LLW concentrate to be realized by the elimination of these areas from the central LLLW system is $\sim 6000$ gal annually, which corresponds to a cost savings of $\sim \$ 300,000$ per year. The cost savings and volume reduction associated with the elimination of this LLW concentrate will need to be compared with the cost and waste production of potential source treatment processes.

To improve the operation of the LLLW evaporator and minimize the LLLW concentrate production rate, larger evaporator batches will have to be run. If the 


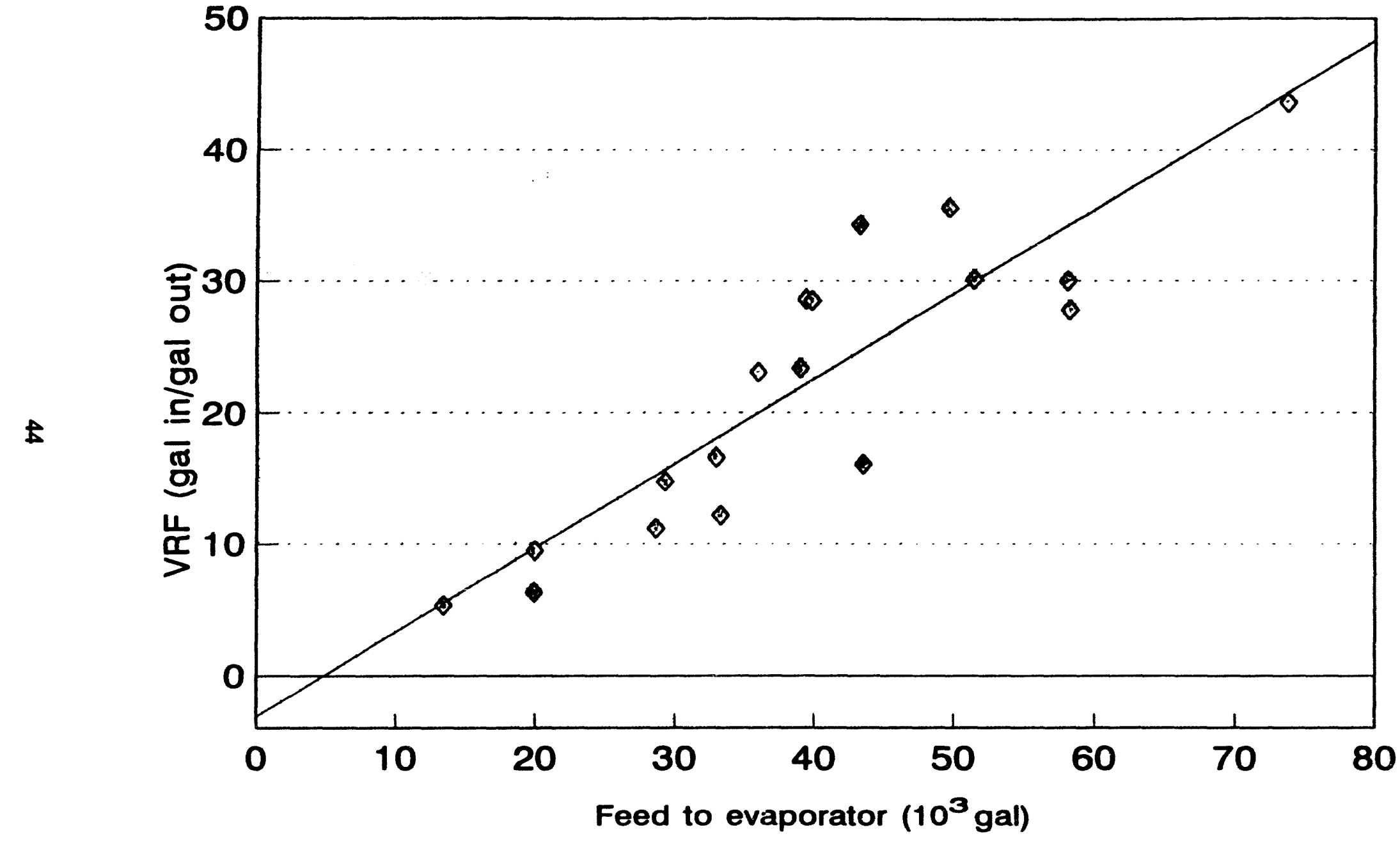

Fig 11. Evaporator performance 1986-1988: VRF as a function of average feed per batch. 
batch size were to be increased to $-55,000 \mathrm{gal}$ of dilute LLLW, a reduction of -5000 gal of concentrate LLLW could be achieved with a cost savings of $-\$ 250,000$ annually.

Table 16. LLLW evaporator data $1987-1988$

\begin{tabular}{lcc}
\hline Campaign dates & $\begin{array}{c}\text { Total feed of LLLW } \\
\text { to evaporator (gal) }\end{array}$ & $\begin{array}{c}\text { Volume reduction } \\
\text { factor (VRF) }\end{array}$ \\
\hline & & \\
$01 / 16 / 87-01 / 30 / 87$ & 32,937 & 16.6 \\
$01 / 30 / 87-02 / 17 / 87$ & 29,291 & 14.8 \\
$02 / 16 / 87-02 / 28 / 87$ & 19,974 & 9.5 \\
$02 / 28 / 87-03 / 29 / 87$ & 38,996 & 23.4 \\
$03 / 23 / 87-06 / 09 / 87$ & 58,267 & 27.8 \\
$06 / 09 / 87-07 / 05 / 87$ & 28,630 & 11.2 \\
$06 / 22 / 87-08 / 24 / 87$ & 43,243 & 34.3 \\
$08 / 13 / 87-10 / 30 / 87$ & 73,760 & 43.6 \\
$10 / 30 / 87-01 / 17 / 87$ & 58,118 & 30.0 \\
$01 / 17 / 87-02 / 06 / 87$ & 43,496 & 16.1 \\
$02 / 04 / 88-03 / 07 / 88$ & 13,428 & 5.3 \\
$03 / 03 / 88-04 / 06 / 88$ & 49,667 & 35.6 \\
$04 / 05 / 88-06 / 25 / 88$ & 39,403 & 28.6 \\
$06 / 25 / 88-08 / 05 / 88$ & 33,258 & 12.2 \\
$08 / 01 / 88-09 / 16 / 88$ & 19,924 & 6.3 \\
$09 / 05 / 88-11 / 10 / 88$ & 51,451 & 30.1 \\
$11 / 07 / 88-12 / 01 / 88$ & 35,970 & 23.1 \\
& & \\
\hline
\end{tabular}

\section{LLLW SYSTEM MASS BALANCE}

The data obtained from generator interviews, surveys of the ORNL literature, the Liquid Waste Weekly Summary Sheets, and sampling information were entered in the LLLW database and were analyzed and compiled to obtain a preliminary mass balance of the LLLW system. Tables 17 and 18, respectively, summarize the nonradioactive and radioactive components entering the LLLW system. These tables are structured on the basis of the stream designations shown in Fig. 12. The generators shown in Fig. 12 and the mass flows summarized in Tables 17 and 18 are intended to represent expected waste generation rates for 1989 and future years. For example, the waste production from the REDC is projected based on an increase in target processing due to new programs, and the LLLW generated in the Fuel Recycle Division has been 
Table 17. Mass flow of nonrediological components in the LLW gyatem (for strean numbers, refer to Flg. 12)

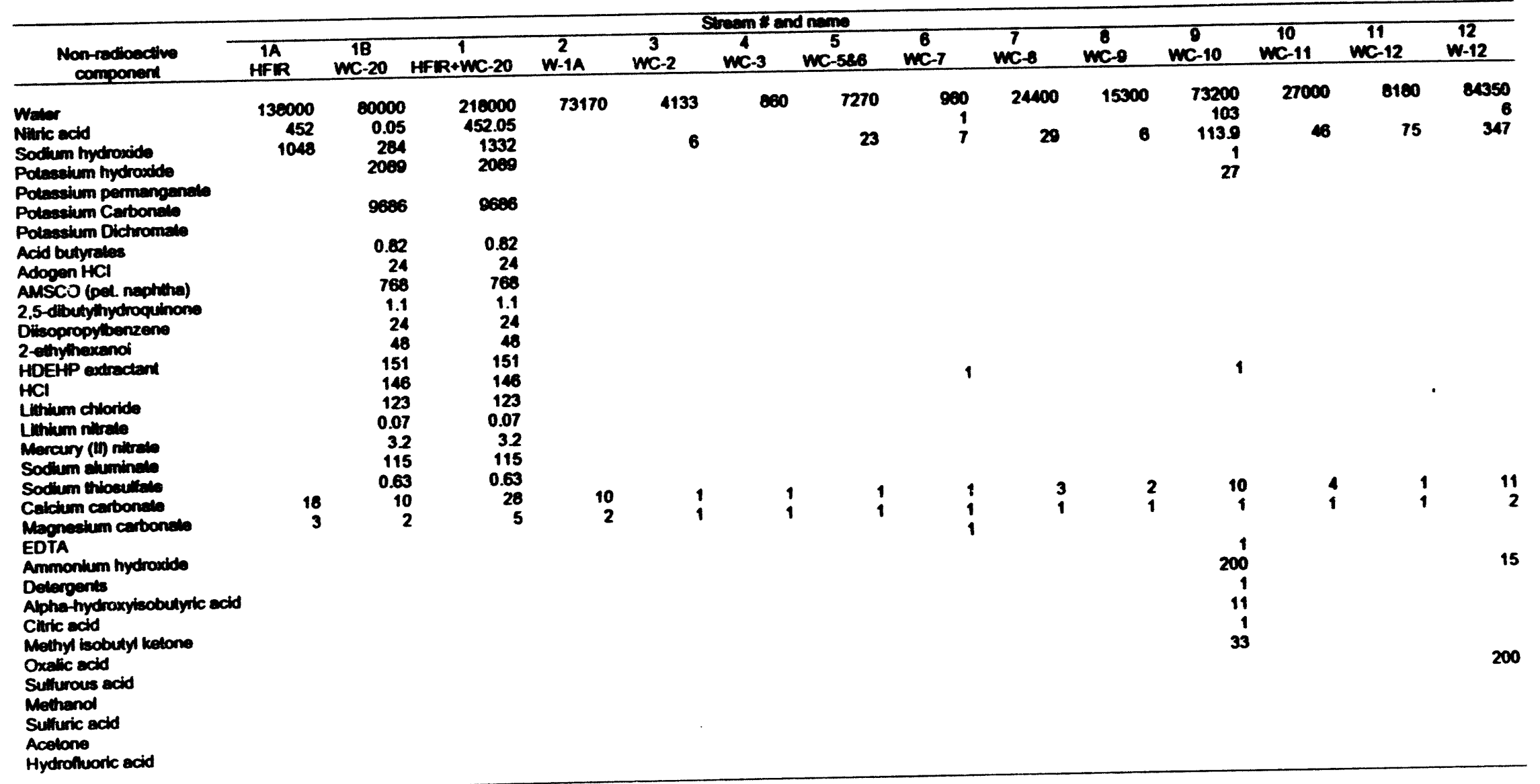


Table 17 (continued)

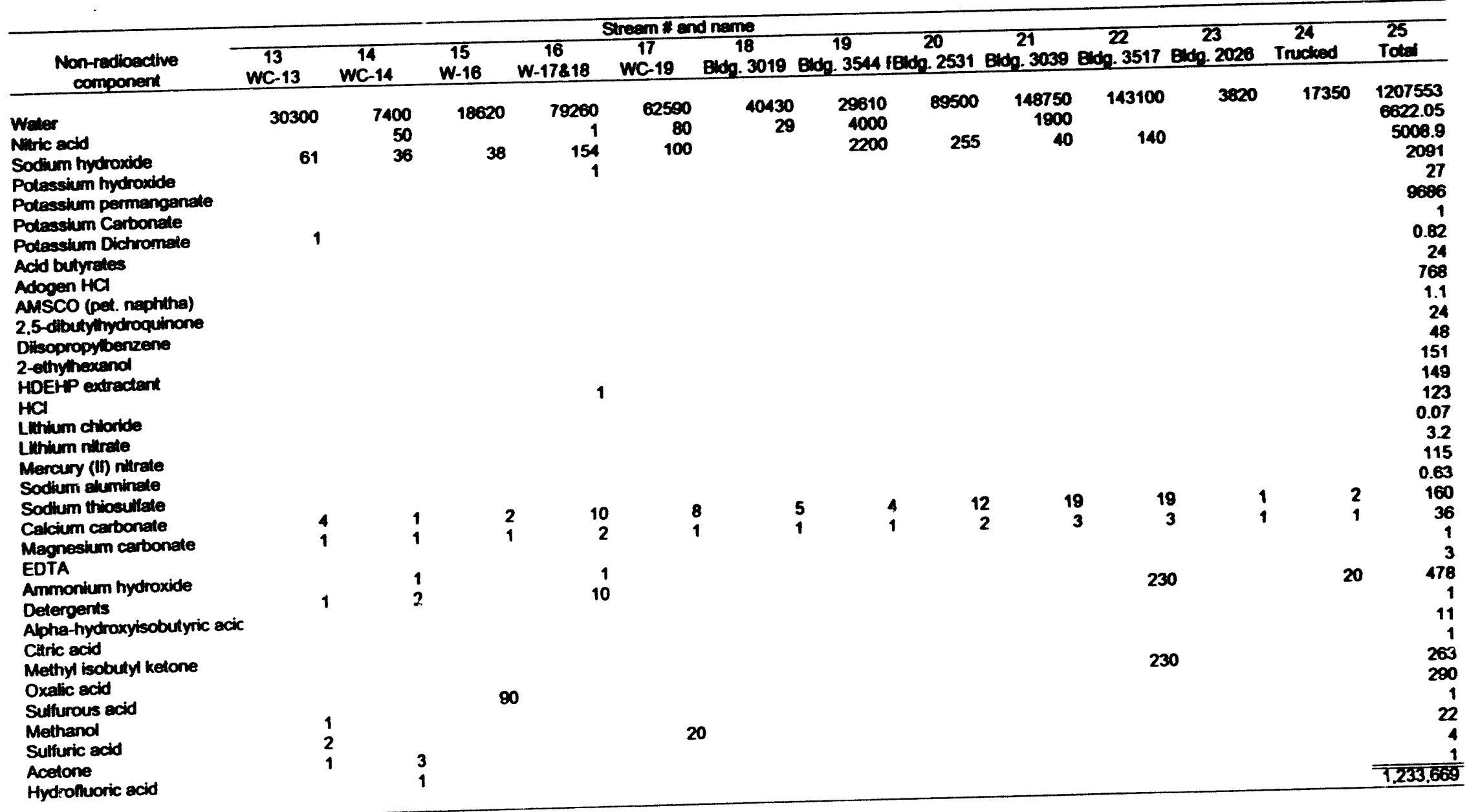




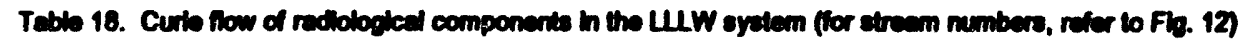

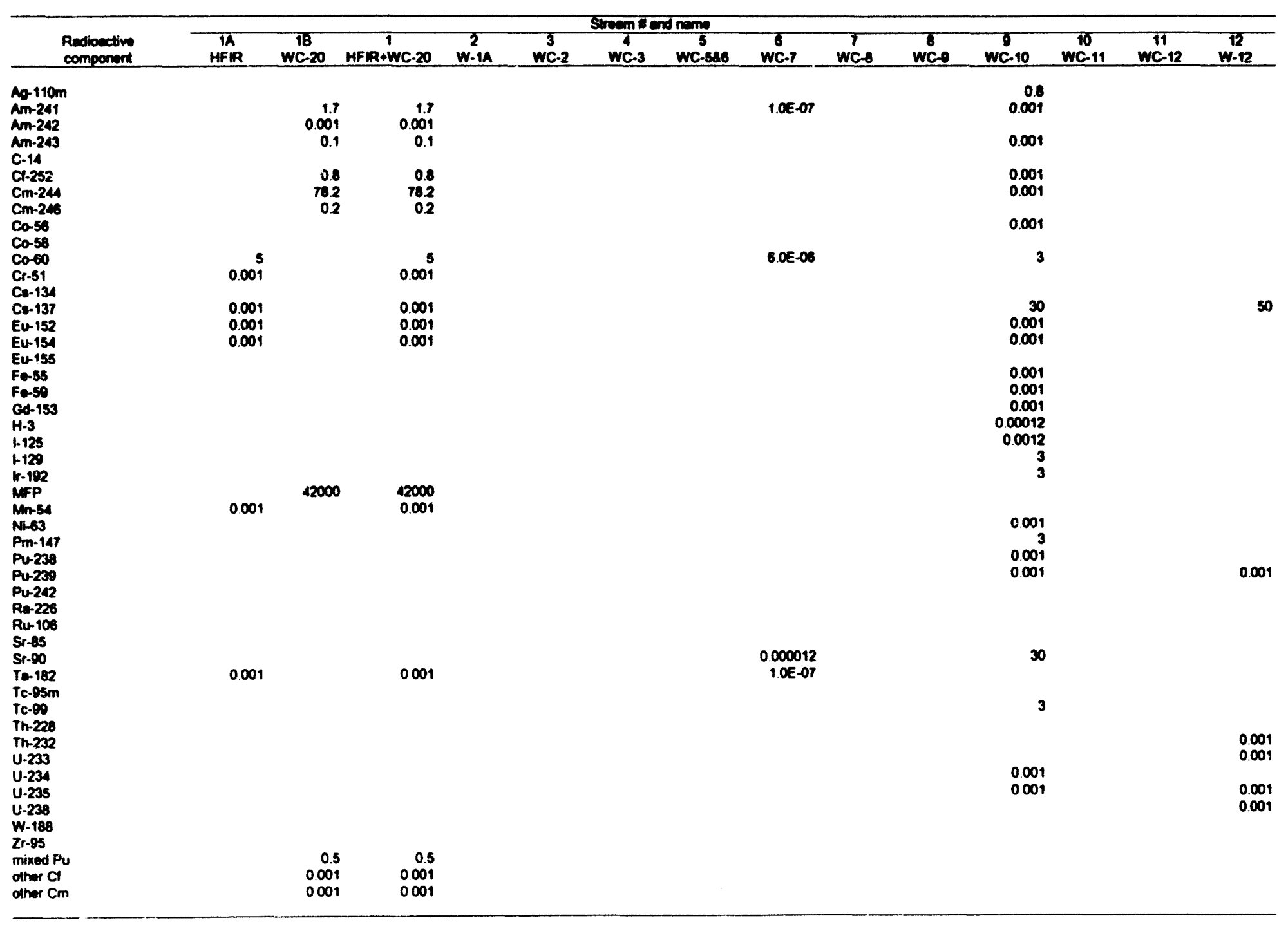


Table 18 (conthued)

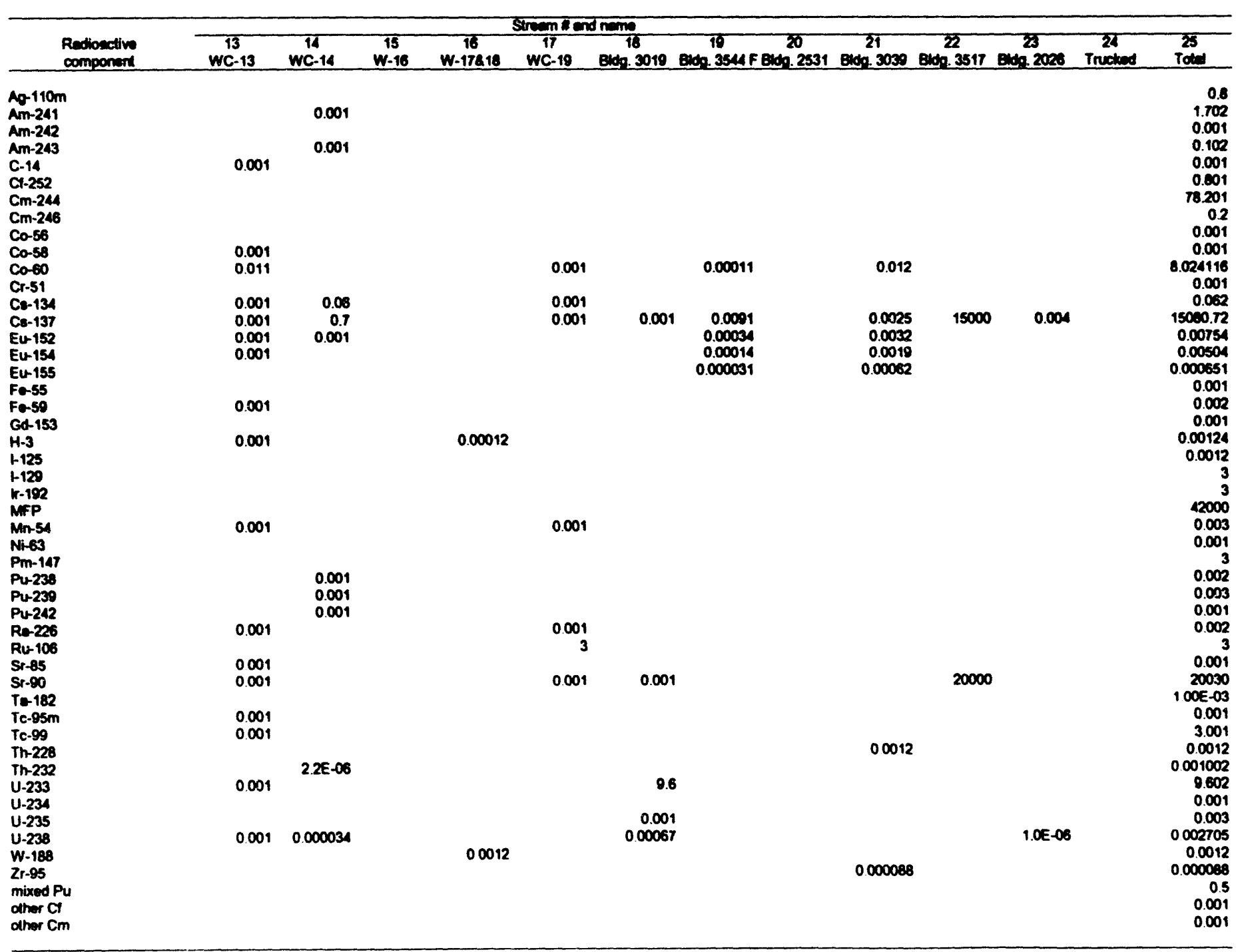




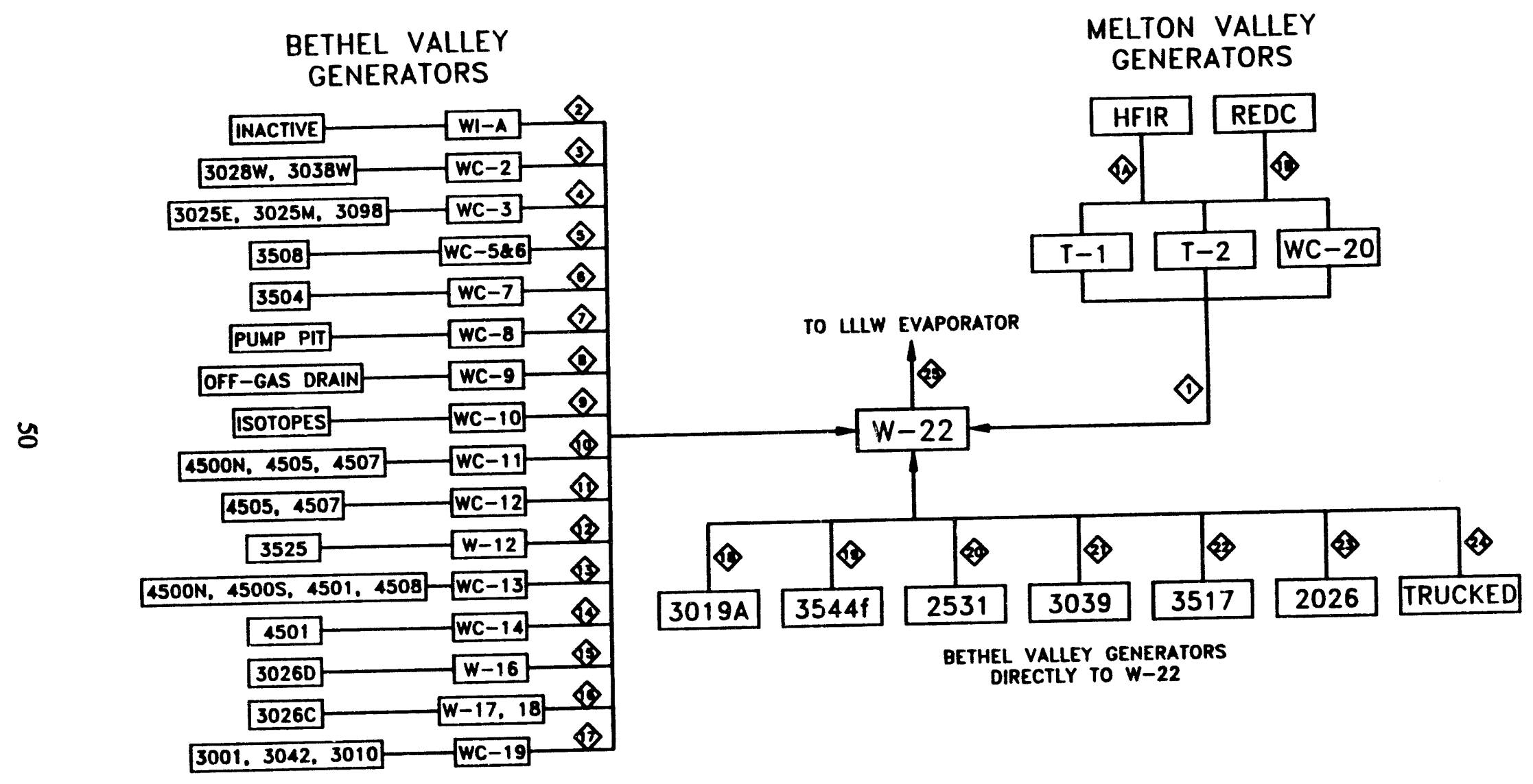

Fig. 12 Stream designations for generators of LLLW. 
eliminated since that waste in no longer collected in the ORNL LLLW system. Inactive tanks not directly contributing waste to the active LLLW CAT System and the LLLW contained in Tank W-21 (PWTP concentrate) are not part of this analysis.

The results of this mass balance compare favorably with previous analytical data obtained concerning the LLLW system; however, further sampling of the LLLW system will be required to verify the mass balance.

The LLLW system data indicate that there are currently or will be in FY 1990 three primary contributors of dissolved solids to the LLLW system; they are the PWTP, the FPDL, and the REDC. The PWTP and FPDL are the primary generators of nitrated waste, and the REDC is the primary generator of potassium carbonate collected in the LLLW system. These results are of particular interest since it is the dissolved solids content that primarily determines the VRF of each evaporator batch. This result compares very well with the results presented in Chap. 5.

The data presented in Table 18 indicate that the primary generators of radionuclides entering the LLLW system are, again, the REDC and the FPDL. While small amounts of radionuclides are generated from almost every area connected to the LLLW system, over 99\% of all of the radionuclides entering the LLLW system are generated at either the REDC or the FPDL. Also, the majority of the transuranic isotopes discharged to the LLLW system are generated at the REDC facility.

These data will serve as the basis to develop a long-term LLLW treatment process, to perform analyses of possible source treatment options, and to determine sampling points in the LLLW system for characterization efforts.

\section{CONCLUSIONS AND RECOMMENDATIONS}

Figure 13 is a summary of the present status of the LLLW database, that is, the data that have been collected to date and those that are currently being obtained. It also indicates general data needed to finalize an analysis of the LLLW system. The database is complete with respect to the following general categories:

1. generator LLLW volume production since 1986,

2. generator facility descriptions, 
3. charge-back information,

4. general LLLW system information pertaining to the physical system,

5. evaporator campaign data, and

6. LLLW concentrate volumes.

Analysis of these limited data has provided the following conclusions:

1. There are two generators that primarily affect the VRF of the evaporator: the PWTP and the FPDL. As new programs develop, the REDC will become a primary contributor to concentrate production.

2. A significant portion of the variability observed in the VRF from evaporator batch to evaporator batch can be attributed to operational effects.

3. Rainfall contributions account for $-20 \%$ of the LLLW collections.

4. There are two primary generators of the radionuclides collected by the LLLW system: the REDC and the FPDL.

5. A working mass balance of the LLLW system has been completed.

Analytical data from the major LLLW generators and certain critical areas of the LLLW system are required before the systems analysis can be completed. Sampling of the primary generators and of the evaporator feed tank, W-22, is necessary to validate the mass balance completed in this study. Based on results of the systems analyses to date, sampling of the REDC waste to determine the specifics of their mixed fission products stream and sampling of the FPDL when cesium and strontium production runs are being made should have top priority. Tank W-22 should be sampled routinely so that the feed to the evaporator can be well characterized and the efficiency of the evaporation process can be monitored.

Once the waste streams from the major generators are well characterized, the feasibility of source treatment at each of the major generators needs to be determined. For this work to be done effectively, a thorough understanding of each process must be gained, and development work will need to be completed in conjunction with the generator. 
Future work will entail the following activities:

1. Completion of the menu-driven, user friendly database. The database will be designed so that a general understanding of personal computer operation will allow ready access to all LLLW system data.

2. The LLLW system will be optimized with respect to source treatment vs a central treatment system. To do this analysis, an estimate of the Low-Level Waste Disposal Development and Demonstration Facility (LLWDDD) Class I and II disposal limits will be required.

3. A flowsheet for centralized LLLW treatment will be developed.

4. If funding becomes available, work is planned with the major generators to explore the different source treatment options available for their use. 


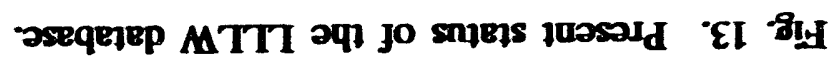

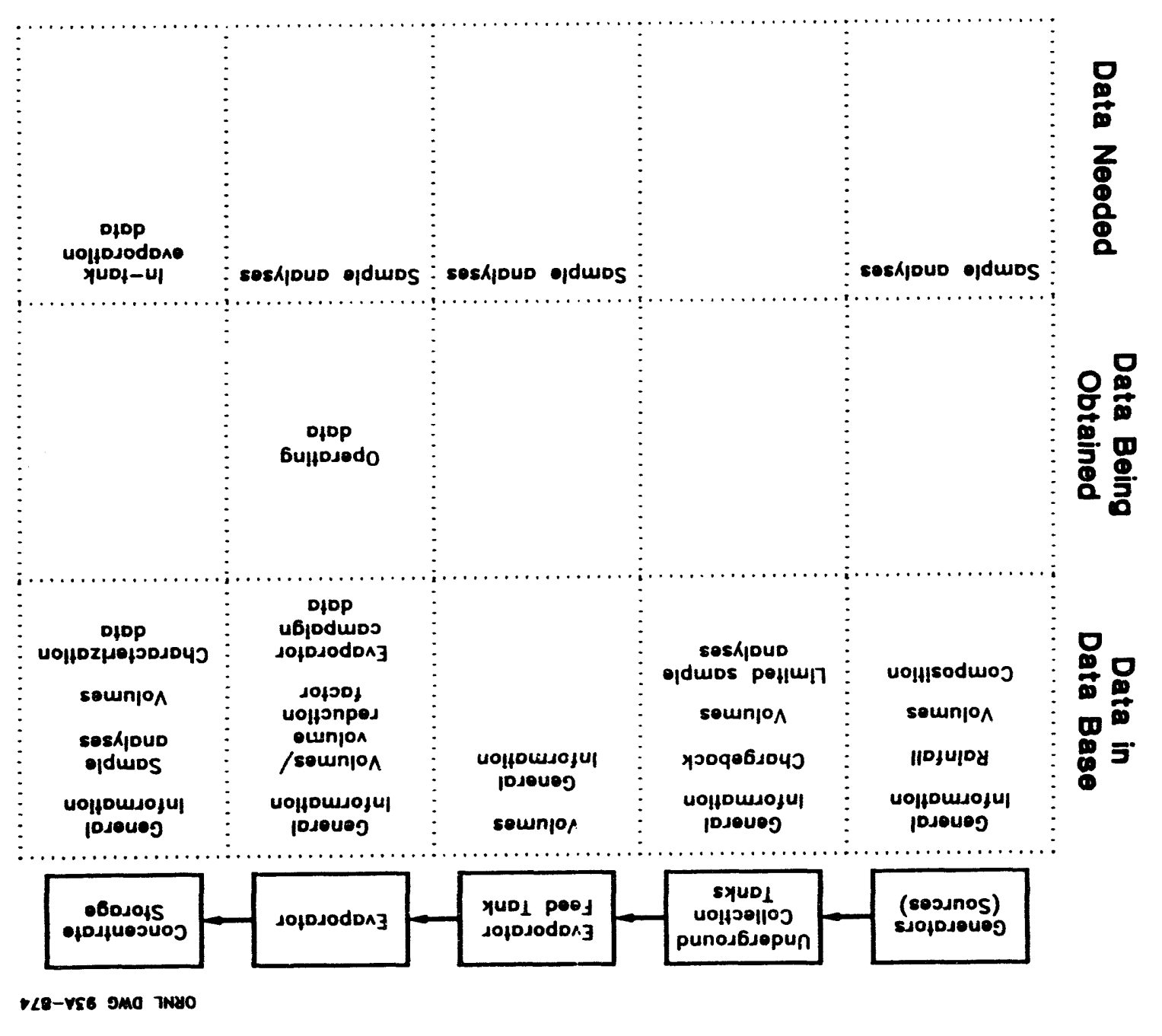




\section{REFERENCES}

1. L. E. Mc Neese et al., Overall Strategy and Program Plan for Management of Radioactively Contaminated Liquid Wastes and Transuranic Sludges at the Oak Ridge National Laboratory, ORNL/TM-10757, Oak Ridge Natl. Lab., December 1988.

2. F. J. Pretez et al., Characterization of Low-Level Liquid Wastes at the Oak Ridge National Laboratory, ORNL/TM-10218, Oak Ridge Natl. Lab., December 1986.

3. J. F. Walker Jr., J. J. Perona, and S. M. Robinson, In-tank Evaporator Demonstrations During 1990/1991 at the ORNL Melton Valley Storage Tanks, ORNL/TM-12036, Oak Ridge Nat. Lab., October 1992. 


\section{INTFRNAL DISTRIBUTION}

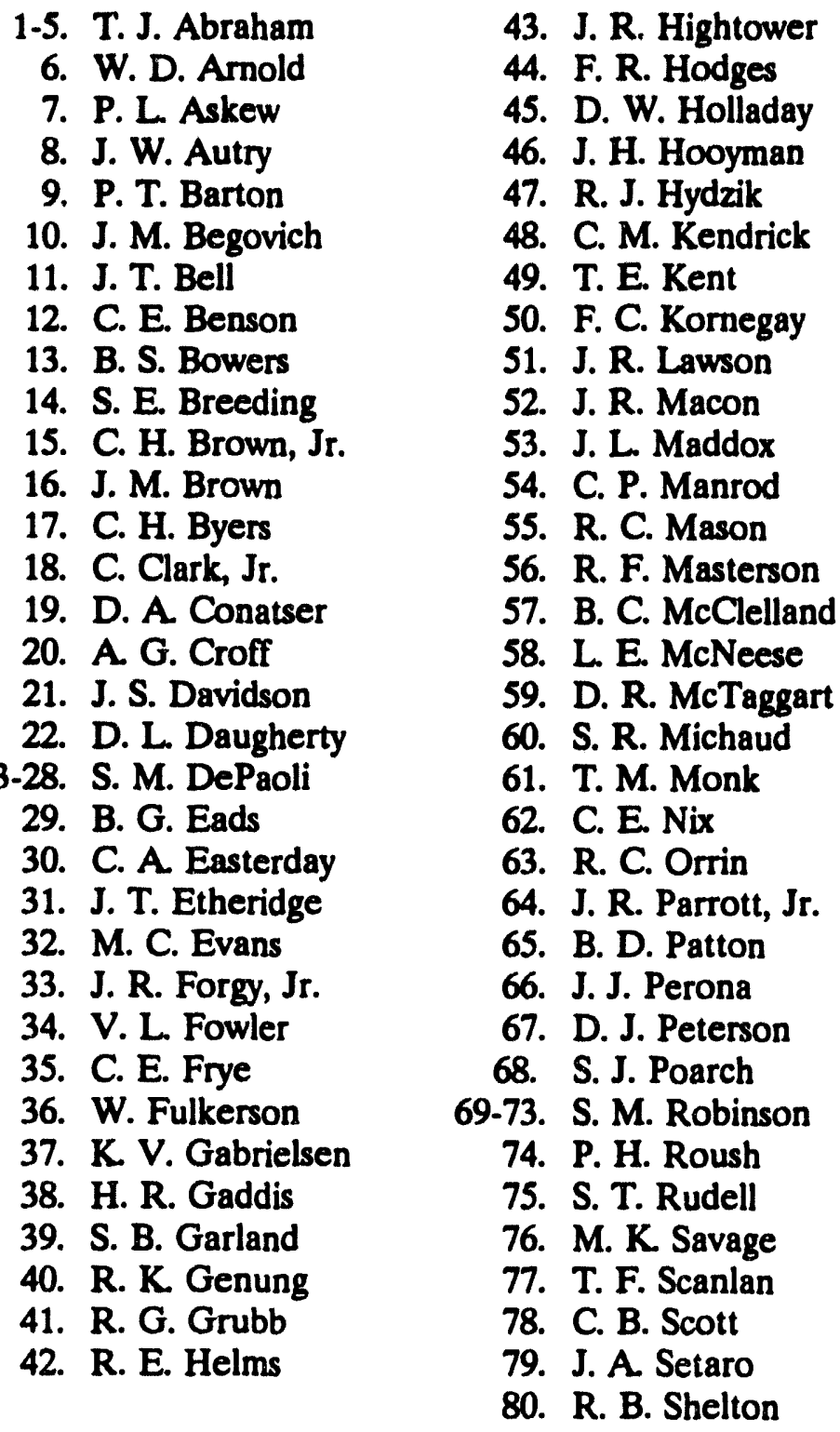

1-5. T. J. Abraham

6. W. D. Amold

7. P. L. Askew

8. J. W. Autry

9. P. T. Barton

10. J. M. Begovich

11. J. T. Bell

12. C. E. Benson

13. B. S. Bowers

14. S. E. Breeding

15. C. H. Brown, Jr.

16. J. M. Brown

17. C. H. Byers

18. C. Clark, Jr.

19. D. A. Conatser

20. A. G. Croff

21. J. S. Davidson

22. D. L. Daugherty

29. B. G. Eads

30. C. A. Easterday

31. J. T. Etheridge

32. M. C. Evans

33. J. R. Forgy, Jr

34. V. L. Fowle

35. C. E. Frye

36. W. Fulkerson

37. K V Gabrielsen

8. H. R Gaddis

39. S. B. Garland
43. J. R. Hightower

44. F. R. Hodges

45. D. W. Holladay

46. J. H. Hooyman

47. R. J. Hydzik

48. C. M. Kendrick

49. T. E. Kent

50. F. C. Kornegay

51. J. R. Lawson

52. J. R. Macon

53. J. L. Maddox

54. C. P. Manrod

55. R. C. Mason

56. R. F. Masterson

57. B. C. McClelland

58. L. E. McNeese

60. S. R. Michaud

61. T. M. Monk

62. C. E. Nix

63. R. C. Orrin

64. J. R. Parrott, Jr.

65. B. D. Patton

66. J. J. Perona

67. D. J. Peterson

73. S. M. Robinson

74. P. H. Roush

75. S. T. Rudell

76. M. K. Savage

77. T. F. Scanlan

80. R. B. Shelton
81. G. W. Sherrill

82. L. R. Simmons

83. J. L. Snyder

84. R. C. Stewart

85. L. E. Stratton

86. J. H. Swanks

87. W. T. Thompson

88. J. R. Trabalka

89. J. R. Travis

90. M. W. Tull

91. D. W. Turner

92. C. K. Valentine

93. R. I. Van Hook

94-99. A. B. Walker

100. D. M. Wasserman

101. J. S. West

102. W. C. Yee

103. D. S. Zill

104. Central Research Library

105. Document Reference Section

106-107. Laboratory Records

108. Laboratory Records-RC

109. ORNL Patent Section

\section{EXTERNAL DISTRIBUTION}

110. Office of Assistant Manager, Energy Research and Development, DOE-OR, P.O. Box 2001, Oak Ridge, TN 37831

111-112. Office of Scientific and Technical Information, P.O. Box 62, Oak Ridge, TN 37831 

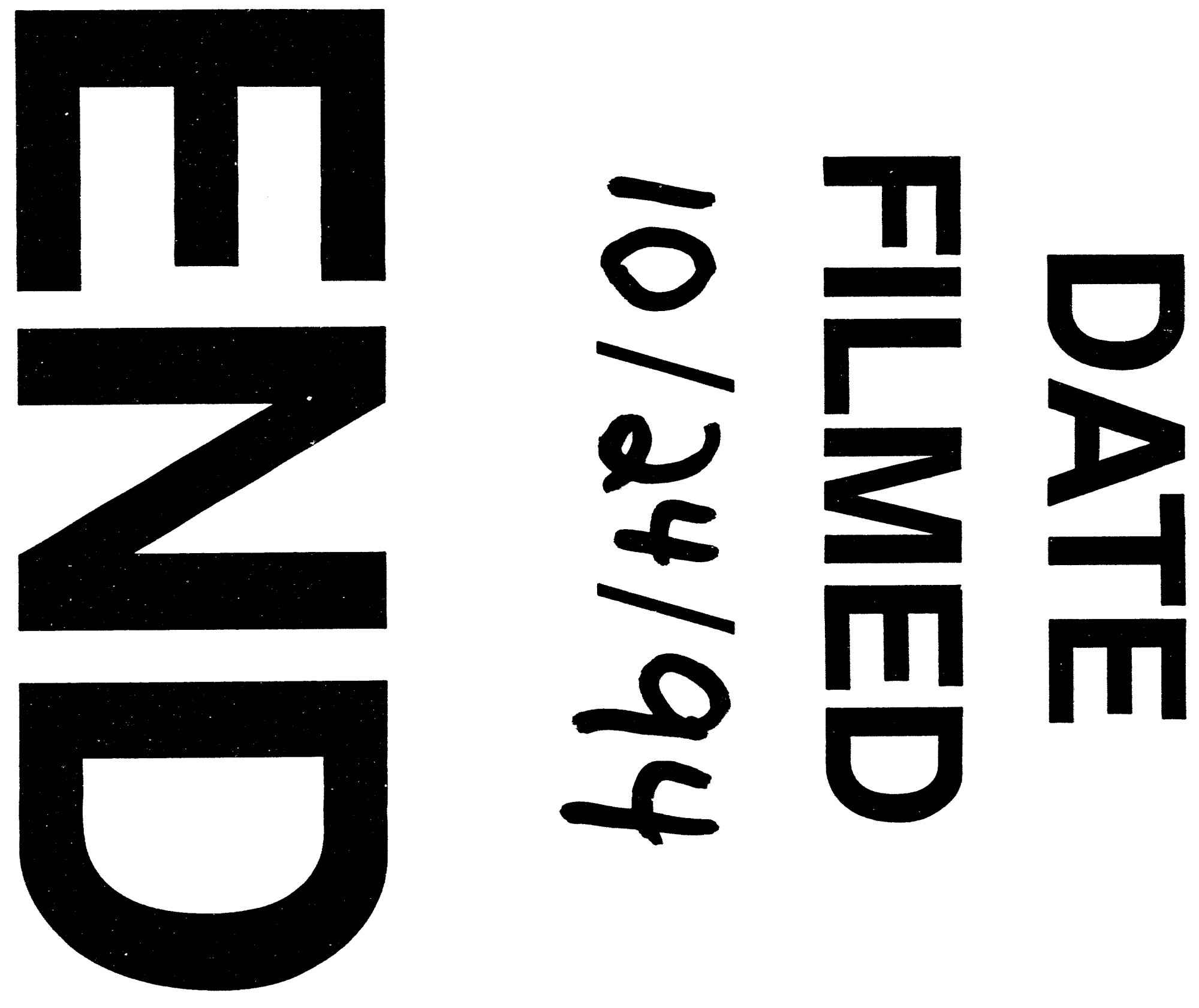


$$
\longrightarrow
$$

